\title{
RAZPRAVE
}

\section{TRENDI TEMPERATUR IN PADAVIN TER TRENDI PRETOKOV REK V IDRIJSKEM HRIBOVJU}

\author{
AVTORJA \\ dr. Mauro Hrvatin \\ Znanstvenoraziskovalni center Slovenske akademije znanosti in umetnosti, Geografski inštitut Antona Melika, \\ Gosposka ulica 13, SI - 1000 Ljubljana, Slovenija; mauro@zrc-sazu.si
}

\section{dr. Matija Zorn}

Znanstvenoraziskovalni center Slovenske akademije znanosti in umetnosti, Geografski inštitut Antona Melika, Gosposka ulica 13, SI - 1000 Ljubljana, Slovenija; matija.zorn@zrc-sazu.si

DOI: $10.3986 / G V 89101$

UDK: 551.58+556.53(497.473)

COBISS: 1.01

\section{IZVLEČEK}

\section{Trendi temperatur in padavin ter trendi pretokov rek $v$ Idrijskem hribovju}

$V$ Slovenji se povprečna temperatura zraka $v$ drugi polovici 20. stoletja in na začetku 21. stoletja zvišuje, medtem ko količina padavin upada. Manjše je tudi število dni s snežno odejo, zmanjšuje pa se tudi višina snežne odeje. Spremembe količine padavin v povezavi s spremembami rabe tal vplivajo na spremembe pretokov rek, ki v zadnjega pol stoletja beležijo upadajoč trend pretokov oziroma zmanjšanje vodnih količin. $V$ članku so predstavljeni trendi temperatur in padavin ter trendi pretokov rek $v$ Idrijskem hribovju med letoma 1961 in 2010. Rezultati na obravnavanem območju kažejo naraščanje letne temperature, padanje količine padavin in števila dni s snežno odejo, v upadanju pa so tudi letni pretoki rek.

\section{KLJUČNE BESEDE}

podnebna geografija, geografija voda, trendi temperature, trendi padavin, trendi pretokov, podnebne spremembe, Idrijsko hribovje

\section{ABSTRACT}

\section{Temperature and precipitation trends and river discharge trends in the Idrija Hills}

In Slovenia, the average air temperature is since the second half of the 20th century and at the beginning of the 21st century increasing, while the amount of precipitation decreases. The number of days with snow cover is also lower, and the height of the snow cover decreases. Changes in the amount of precipitation associated with changes in land use affect the changes in river discharges, which in the last half century have recorded a downward trend or a decrease in water quantities. The article presents trends in temperatures and precipitation and trends in river discharges in the Idrija hills between 1961 and 2010. The results show the increase in the annual temperature, the drop in precipitation and the number of days with snow cover, as well as in river discharges.

\section{KEY WORDS}

climate geography, hydrogeography, temperature trends, precipitation trends, discharge trends, climate change, Idrija hills

Uredništvo je prispevek prejelo 1. septembra 2017. 


\section{Uvod}

Idrijsko hribovje obsega sredogorski svet ob zgornjem toku Idrijce in se razprostira na prehodu iz alpskega v dinarski svet. Na severu ga omejujejo Julijske Alpe, na vzhodu Cerkljansko in Škofjeloško hribovje, na jugu Trnovski gozd in na severozahodu Banjšice. Precejšen del ozemlja sestavlja razgiban kraški svet, v katerega so reke in potoki vrezali debrske doline in grape ter ga razkosale na posamezne planote. Vojskarska planota se razprostira med dolinami Trebuščice, Kanomljice in zgornje Idrijce, Šebreljska planota se dviga nad velikim zavojem Idrijce ob njenem srednjem toku, Šentviška planota pa leži med Bačo in spodnjo Idrijco (Černe in Urbanc 1998).

Nadmorske višine v hribovju se gibljejo med 156 in $1170 \mathrm{~m}$. Najvišja vzpetina južnega hrbta hribovja je Planinca $(1170 \mathrm{~m})$ pri Vojskem, severni hrbet pa se najvišje vzpne na Jelenku $(1107 \mathrm{~m})$ pri Idrijskih Krnicah. Najnižja točka leži na višini $156 \mathrm{~m}$ ob sotočju Idrijce in Bače.

Ker vplivi Jadranskega morja le redko sežejo prek Trnovskega gozda, v Idrijskem hribovju prevladuje celinsko podnebje. Planote nad $1000 \mathrm{~m}$ imajo gorsko podnebje s svežimi poletji in dolgo zimo ter debelo in dolgotrajno snežno odejo (Černe in Urbanc 1998, 346).

Pomembne so tudi krajevne reliefne značilnosti: izredna razčlenjenost površja, velike višinske razlike, usmerjenost dolin, ekspozicija pobočij in tip reliefa. Močno razčlenjen relief pospešuje vertikalno mešanje zraka. Mrzel zrak spolzi z večjih višin v globoko vrezane doline in kotline ter se tam ujame. Nastane toplotni obrat, zaradi katerega so temperature v dnu dolin nižje kot nekaj sto metrov višje. Temperaturni obrat je najbolj izrazit decembra, pogost pa je tudi januarja in februarja (Topole in Zorn 2010, 21).

V Idriji $(330 \mathrm{~m})$ je bila v obdobju $1926-1965$ povprečna letna temperatura $9,5^{\circ} \mathrm{C}$, januarska $-2,4^{\circ} \mathrm{C}$ in julijska $18,1^{\circ} \mathrm{C}$ (Meze 1987, 13), na Vojskem $(1067 \mathrm{~m})$ pa je bila v obdobju 1961-2010 povprečna letna temperatura $6,1^{\circ} \mathrm{C}$, januarska $-2,9^{\circ} \mathrm{C}$ in julijska $15,5^{\circ} \mathrm{C}$.

Letna višina padavin v Idrijskem hribovju koleba od 1800 do $3000 \mathrm{~mm}$ in je med najvišjimi v Sloveniji (Zupančič 1998, 99). Padavine so razporejene prek celega leta in jih je dovolj tudi v obdobju rasti. Zaradi možnih obilnih dnevnih padavin in hudourniškega značaja vodotokov prihaja do poplav in zemeljskih plazov (Topole in Zorn 2010, 23).

Snežne razmere se zaradi velikih razlik v nadmorski višini precej razlikujejo. V Idriji je snežna odeja v povprečju debela okoli $0,5 \mathrm{~m}$ in traja največ dva do tri mesece, na Vojskem pa je debela približno meter in traja od 4 do 6 mesecev (Topole in Zorn 2010, 23).

Idrijske planote so veliki zbiralniki vode, $v$ dnu dolin pa so močnejši kraški izviri. Za tok so vode najpogosteje izkoristile dinarske prelomnice, tečejo pa tudi v smeri prečno nanje, saj je v preteklosti zaradi razlik v tektoniki in v prevladujočih geomorfnih procesih večkrat prišlo do pretočitev (Topole in Zorn 2010, 17).

Vode s hribovja se stekajo v Idrijco, ki je z $48 \mathrm{~km}$ najdaljši pritok Soče. S pritoki, med katerimi so najpomembnejši Belca, Jezernica, Zala, Kanomljica, Cerknica, Trebuščica in Bača, teče po globoko vrezanih, tesnih dolinah Idrijskega hribovja ter ob severni strani Trnovskega gozda. Praviloma sledijo vsi večji pritoki tektonskim prelomnicam v podolžni, dinarski smeri (Černe in Urbanc 1998, 344).

Idrijca ima dinarski dežno-snežni pretočni režim, za katerega je značilno, da sta spomladanski in jesenski višek precej izenačena. Glavni nižek je poleti, običajno avgusta, sekundarni pa januarja in februarja (Frantar in Hrvatin 2005).

Od sredine 19. stoletja, ko se je končala "mala ledena doba", so se temperature v Evropi in širše zviševale. V 20. stoletju se je globalna temperatura zvišala za $0,74 \pm 0,18^{\circ} \mathrm{C}(1906-2005)$. Naraščanje temperatur $\mathrm{v}$ drugi polovici stoletja se je skoraj podvojijo $\mathrm{v}$ primerjavi s celotnim stoletjem

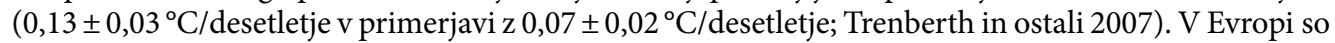
se v 20. stoletju maksimalne in minimalne temperature pozimi zvišale za $1^{\circ} \mathrm{C}$ na 100 let, poleti pa za $0,8^{\circ} \mathrm{C}$ na 100 let (Milošević in ostali 2017,2). V Slovenji se je povprečna temperatura zraka v drugi polovici 20. stoletja (1956-2005) statistično značilno povečala za $1,4 \pm 0,6^{\circ} \mathrm{C}$, najbolj v mestih in manj na podeželju. Projekcije za 21. stoletje kažejo dvig temperature zraka v hladni polovici leta za približno $3^{\circ} \mathrm{C}$ ( razpon od 1,5 do $7^{\circ} \mathrm{C}$ ) in v topli polovici leta za $3,5^{\circ} \mathrm{C}$ (razpon od 1,5 do $8^{\circ} \mathrm{C}$ ) (Kajfež-Bogataj 2006, 171-172). 
Spremembe količine padavin na večjem delu slovenskega ozemlja niso statistično značilne (Kajfež-Bogataj 2006, 172). Kljub temu so opazni trendi, ki nakazujejo manjše količine padavin, na primer v Ljubljani od $-36 \mathrm{~mm}$ do -43 na 100 let, v Mariboru $-40 \mathrm{~mm}$ na 100 let in Trstu $-80 \mathrm{~mm}$ na 100 let (Ogrin 2003, 121; Žiberna 2011, 109-110).

V Sloveniji opažamo tudi zmanjšanje števila dni s snežno odejo. V Ljubljani se je v obdobju 1950-2009 število dni s snežno odejo zmanjševalo za tri dni na desetletje, na ravni države pa za 2 do 4 dni na desetletje (Dolinar 2010, 4, 12). Zaradi višjih zimskih temperatur (Milošević in ostali 2017, 14) in manjšega deleža snega v zimskih padavinah (Dolinar 2010, 12) beležimo tudi tanjšanje snežne odeje ter manjšanje slovenskih ledenikov (Gabrovec in ostali 2013; 2014). Na Kredarici beležijo v zadnjih trideset letih manjšo povprečno višino snega glede na 130-letno obdobje pred tem (Dolinar 2010, 4, 12).

Spremembe količine padavin v povezavi s spremembami rabe tal (Ulaga, Kobold in Frantar 2008, 9) vplivajo na spremembe pretokov rek. Za večino vodomernih postaj po Sloveniji je v zadnjih petdeset letih značilen upadajoč trend srednjih dnevnih pretokov (Frantar, Kobold in Ulaga 2008, 60; Kovačič 2016; Hrvatin in Zorn 2017) oziroma zmanjšanje vodnih količin (Ulaga, Kobold in Frantar 2008, 9).

$\mathrm{V}$ članku so predstavljeni trendi temperatur in padavin ter trendi pretokov rek v Idrijskem hribovju med letoma 1961 in 2010.

\section{Metode}

Za ugotavljanje trenda spreminjanja izbranih podnebnih in hidroloških spremenljivk (preglednica 1) v približno zadnjega pol stoletja (obdobje 1961-2010), smo na izbranih temperaturnih, padavinskih in vodomernih postajah (preglednici 2 in 3; slika 1) uporabili Mann-Kendallov test ter Theil-Senovo cenilko, krajše imenovano tudi Senov naklon. Mann-Kendallov test je neparametričen test za ugotavljanje monotonega trenda. Ni občutljiv na podatkovne osamelce in temelji na testni statistiki. Pozitivna vrednost testne statistike označuje naraščajoč trend, negativna vrednost testne statistike pa kaže na padajoč trend (Kraner Šumenjak in Šuštar 2011). Senov naklon je najpogosteje uporabljani neparametrični test za ugotavljanje linearnega časovnega trenda (Kraner Šumenjak in Šuštar 2011). V primerjavi z linearno regresijo je Senov naklon bistveno bolj natančen pri asimetrično porazdeljenih podatkih in pri normalno porazdeljenih podatkih daje povsem primerljive rezultate metodi najmanjših kvadratov (Kovačič 2016, 10; Kovačič, Kolega in Brečko Grubar 2016, 24).

Pri izračunih vrednosti Mann-Kendallovega testa in Senovega naklona smo si pomagali s prosto dostopnim programskim orodjem MAKESENS (Mann-Kendall test for trend and Sen's slope estimates) 1.0 (medmrežje 1; Salmi in ostali 2002).

V preglednicah podnebnih in hidroloških spremenljivk so poleg vrednosti Mann-Kendallovega testa in Senovega naklona predstavljene še vrednosti ravni zaupanja, (začetnega) trendnega stanja leta 1961, (končnega) trendnega stanja leta 2010 ter absolutne in relativne trendne razlike.

Raven zaupanja je v statistiki verjetnost, da izračunani interval zaupanja vključuje vrednost ocenjevanega parametra. Višja raven zaupanja $\mathrm{v}$ našem primeru pomeni večjo verjetnost, da ugotovljeni trend naraščanja ali upadanja izbrane spremenljivke dejansko obstaja.

Začetno trendno stanje leta 1961 je vrednost izbrane spremenljivke za leto 1961, ki smo jo odčitali na trendni premici, končno trendno stanje leta 2010 pa je vrednost izbrane spremenljivke za leto 2010, ki smo jo prav tako odčitali na trendni premici. Absolutna trendna razlika je razlika med končnim in začetnim trendnim stanjem, relativna trendna razlika pa je razlika med končnim in začetnim trendnim stanjem izražena v odstotkih.

Trendno vrednost za izbrano leto lahko izračunamo po enačbi:

trendna vrednost za leto $\mathrm{x}=$ Senov naklon $\times($ trendno leto $\mathrm{x}-$ začetno trendno leto $)+$ začetna trendna vrednost. 
Mauro Hrvatin, Matija Zorn $\quad$ Trendi temperatur in padavin ter trendi pretokov rek v Idrijskem hribovju

Preglednica 1: Obravnavane podnebne in hidrološke spremenljivke.

podnebne spremenljivke

povprečna letna temperatura zraka

letna količina padavin

letno število dni s padavinami nad $0,1 \mathrm{~mm}$

letno število dni s snežno odejo

hidrološke spremenljivke

absolutni minimalni letni pretoki

povprečni minimalni letni pretoki

povprečni srednji letni pretoki

povprečni maksimalni letni pretoki

absolutni maksimalni letni pretoki

\section{Podatki}

\subsection{Podnebne spremenljivke}

Podatke o podnebnih spremenljivkah smo pridobili na Agenciji Republike Slovenije za okolje (Arhiv meteoroloških ... 2017). V analizo smo vključili več postaj iz Idrijskega hribovja in širše okolice (preglednica 2; slika 1). Uporabili smo podatke s postaj z več desetletnim nizom meritev.

Preglednica 2: Obravnavane vremenske postaje s časovnimi nizi meritev ( ${ }^{*}$ snežna odeja).

\begin{tabular}{|c|c|c|c|c|c|}
\hline & $\begin{array}{l}\text { vremenska } \\
\text { postaja }\end{array}$ & občina & $\begin{array}{l}\text { nadmorska } \\
\text { višina }(\mathrm{m})\end{array}$ & $\begin{array}{c}\text { časovni } \\
\text { niz }\end{array}$ & $\begin{array}{c}\text { število letnih } \\
\text { meritev }\end{array}$ \\
\hline \multirow{7}{*}{$\begin{array}{l}\text { temperaturna } \\
\text { postaja }\end{array}$} & Čepovan & Nova Gorica & 596 & $1961-2010$ & 50 \\
\hline & $\begin{array}{l}\text { Javorje nad } \\
\text { Poljanami }\end{array}$ & $\begin{array}{l}\text { Gorenja vas - } \\
\text { Poljane }\end{array}$ & 700 & $1961-2010$ & 50 \\
\hline & Nanos - Ravnik & Vipava & 905 & $1961-2010$ & 50 \\
\hline & Nova Gorica & Nova Gorica & 112 & $1961-2010$ & 50 \\
\hline & Slap & Vipava & 130 & $1961-2006$ & 50 \\
\hline & Vojsko & Idrija & 1067 & $1961-2010$ & 50 \\
\hline & Vrhnika & Vrhnika & 293 & $1961-2010$ & 50 \\
\hline \multirow[t]{9}{*}{$\begin{array}{l}\text { padavinska } \\
\text { postaja }\end{array}$} & $\begin{array}{l}\text { Črni Vrh } \\
\text { nad Idrijo }\end{array}$ & Idrija & 683 & $1961-2010$ & 48 \\
\hline & Hotedršica & Logatec & 550 & $1961-2010$ & $50,49^{*}$ \\
\hline & Idrija & Idrija & 333 & 1961-1999 & 36 \\
\hline & Logatec & Logatec & 485 & $1961-2010$ & 50 \\
\hline & Mrzla Rupa & Idrija & 842 & $1961-2010$ & 50 \\
\hline & $\mathrm{Na}$ stanu & Cerkno & 989 & $1961-2010$ & 46 \\
\hline & Otlica & Ajdovščina & 812 & $1961-2010$ & 50 \\
\hline & Slap & Vipava & 130 & $1961-2006$ & 46 \\
\hline & Vojsko & Idrija & 1067 & $1961-2010$ & 50 \\
\hline
\end{tabular}




\subsection{Hidrološke spremenljivke}

Podatke o hidroloških spremenljivkah smo pridobili na Agenciji Republike Slovenije za okolje (Arhiv hidroloških ... 2017). V analizo smo vključili več postaj iz Idrijskega hribovja in širše okolice (preglednica 3; slika 1). Uporabili smo podatke s postaj z več desetletnim nizom meritev.

Preglednica 3: Obravnavane vodomerne postaje s časovnimi nizi meritev.

\begin{tabular}{lllccc}
\hline $\begin{array}{l}\text { vodomerna } \\
\text { postaja }\end{array}$ & vodotok & občina & $\begin{array}{c}\text { nadmorska } \\
\text { višina }(\mathrm{m})\end{array}$ & $\begin{array}{c}\text { časovni } \\
\text { niz }\end{array}$ & $\begin{array}{c}\text { število letnih } \\
\text { meritev }\end{array}$ \\
\hline Podroteja & Idrijca & Idrija & 327 & $1961-2010$ & 50 \\
Žiri & Poljanska Sora & Žiri & 475 & $1961-2010$ & 45 \\
Hotedršica & Hotenjka & Logatec & 543 & $1961-2010$ & 22 \\
Reka & Idrijca & Cerkno & 229 & $1961-2010$ & 29 \\
Cerkno & Cerknica & Cerkno & 296 & $1961-2006$ & 46 \\
Dolenja Trebuša & Trebuščica & Tolmin & 186 & $1961-2010$ & 50 \\
Ajdovščina & Hubelj & Ajdov̌čina & 107 & $1961-2010$ & 50 \\
\hline
\end{tabular}

Slika 1: Lokacije temperaturnih, padavinskih in vodomernih postaj, obravnavanih v analizi. str. 14 
Mauro Hrvatin, Matija Zorn Trendi temperatur in padavin ter trendi pretokov rek v Idrijskem hribovju

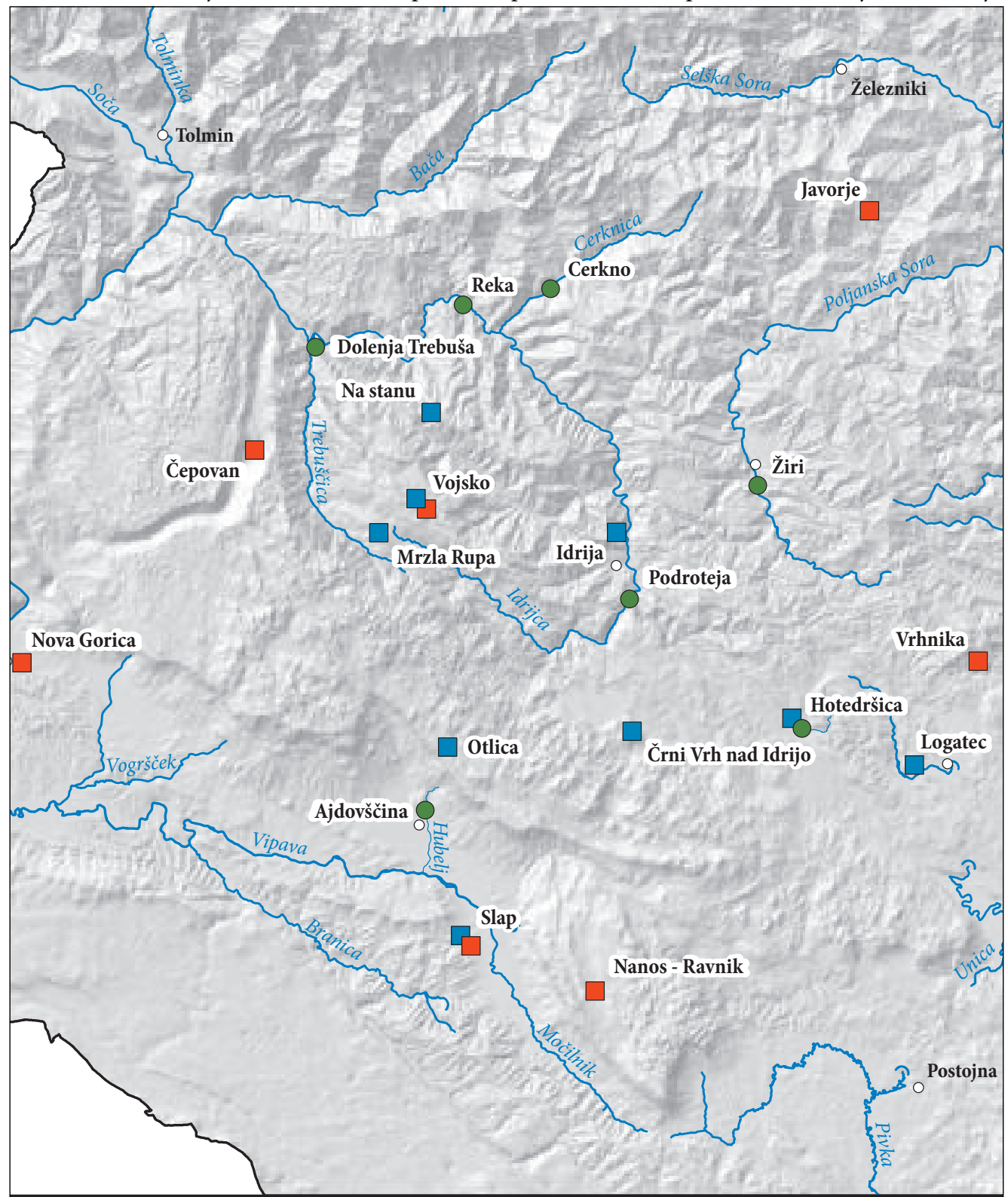

Legenda

padavinska postaja

$\square \quad$ temperaturna postaja

vodomerna postaja 


\section{Rezultati}

\subsection{Podnebne spremenljivke}

V okviru podnebnih spremenljivk smo obravnavali (preglednica 1): (1) trende povprečne letne temperature zraka, (2) trende letne količine padavin, (3) trende letnega števila dni s padavinami nad 0,1 mm in (4) trende letnega števila dni s snežno odejo.

\subsubsection{Povprečna letna temperatura zraka}

Trendi povprečne letne temperature zraka v obdobju od 1961 do 2010 so na vseh sedmih obravnavanih temperaturnih postajah podobni in kažejo na izrazito naraščanje (preglednica 4, slika 2). Značilna je tudi izredno visoka raven zaupanja, ki skoraj na vseh postajah dosega ali celo presega $99 \%$. Manjšo izjemo predstavlja le temperaturna postaja Slap v Vipavski dolini, pa še tam je raven zaupanja $95 \%$.

V obravnavanem obdobju (1961-2010) je temperatura na postajah Čepovan, Javorje, Nanos - Ravnik, Nova Gorica in Vrhnika v povprečju letno narasla od 0,032 do $0,035^{\circ} \mathrm{C}$, kar pomeni, da so se v zadnjega pol stoletja na omenjenih postajah temperature zvišale za $1,59-1,70{ }^{\circ} \mathrm{C}$. Absolutna temperaturna razlika v obdobju od 1961 do 2010 je največja na postaji Vrhnika, kjer je temperatura narasla za $1,7^{\circ} \mathrm{C}$, relativna temperaturna razlika pa je največja na postaji Nanos - Ravnik, kjer je temperaturni dvig $25,5 \%$.

Nekoliko manjši temperaturni dvig beležita postaji Slap in Vojsko. Na Slapu se je v obravnavanem polstoletnem obdobju temperatura zvišala za $0,81^{\circ} \mathrm{C}$, na Vojskem pa za $0,91^{\circ} \mathrm{C}$.

Preglednica 4: Trendi povprečnih letnih temperatur v obdobju od 1961 do 2010.

\begin{tabular}{lccccccc}
\hline $\begin{array}{l}\text { temperaturna } \\
\text { postaja }\end{array}$ & $\begin{array}{c}\text { Mann- } \\
\text { Kendallov } \\
\text { test }\end{array}$ & $\begin{array}{c}\text { raven } \\
\text { zaupanja }\end{array}$ & $\begin{array}{c}\text { Senov } \\
\text { naklon }\end{array}$ & $\begin{array}{c}\text { trendno } \\
\text { stanje } \\
1961\end{array}$ & $\begin{array}{c}\text { trendno } \\
\text { stanje } \\
2010\end{array}$ & $\begin{array}{c}\text { trendna } \\
\text { razlika } \\
1961-2010\end{array}$ & $\begin{array}{c}\text { trendna } \\
\text { razlika } \\
1961-2010\end{array}$ \\
\hline & $\mathrm{Z}$ & $\%$ & $\mathrm{Q}$ & ${ }^{\circ} \mathrm{C}$ & ${ }^{\circ} \mathrm{C}$ & ${ }^{\circ} \mathrm{C}$ & $\%$ \\
\hline Čepovan & 4,56 & 99,9 & 0,032 & 8,04 & 9,63 & 1,59 & 19,78 \\
Javorje & 4,59 & 99,9 & 0,033 & 7,73 & 9,37 & 1,64 & 21,22 \\
Nanos - Ravnik & 4,94 & 99,9 & 0,034 & 6,58 & 8,26 & 1,68 & 25,53 \\
Nova Gorica & 5,17 & 99,9 & 0,033 & 11,45 & 13,08 & 1,63 & 14,24 \\
Slap & 2,13 & 95,0 & 0,017 & 11,57 & 12,38 & 0,81 & 7,00 \\
Vojsko & 2,87 & 99,0 & 0,019 & 6,05 & 6,96 & 0,91 & 15,04 \\
Vrhnika & 4,78 & 99,9 & 0,035 & 9,05 & 10,75 & 1,70 & 18,78 \\
\hline
\end{tabular}

\subsubsection{Letna količina padavin}

V nasprotju s trendi temperature, ki kažejo naraščanje, so trendi letne količine padavin v obdobju od 1961 do 2010 na vseh devetih obravnavanih padavinskih postajah padajoči (preglednica 5, slika 3). Raven zaupanja je spremenljiva. Na postajah Hotedršica in Idrija ne dosega niti $90 \%$, medtem ko je na postajah Mrzla Rupa, Na stanu (Šebreljski Vrh), Otlica in Vojsko $99 \%$.

V obravnavanem obdobju (1961-2010) je količina letnih padavin na večini postaj (Črni Vrh, Logatec, Mrzla Rupa, Na stanu (Šebreljski Vrh), Otlica, Slap in Vojsko) v povprečju letno upadla od 5 do $11 \mathrm{~mm}$, 


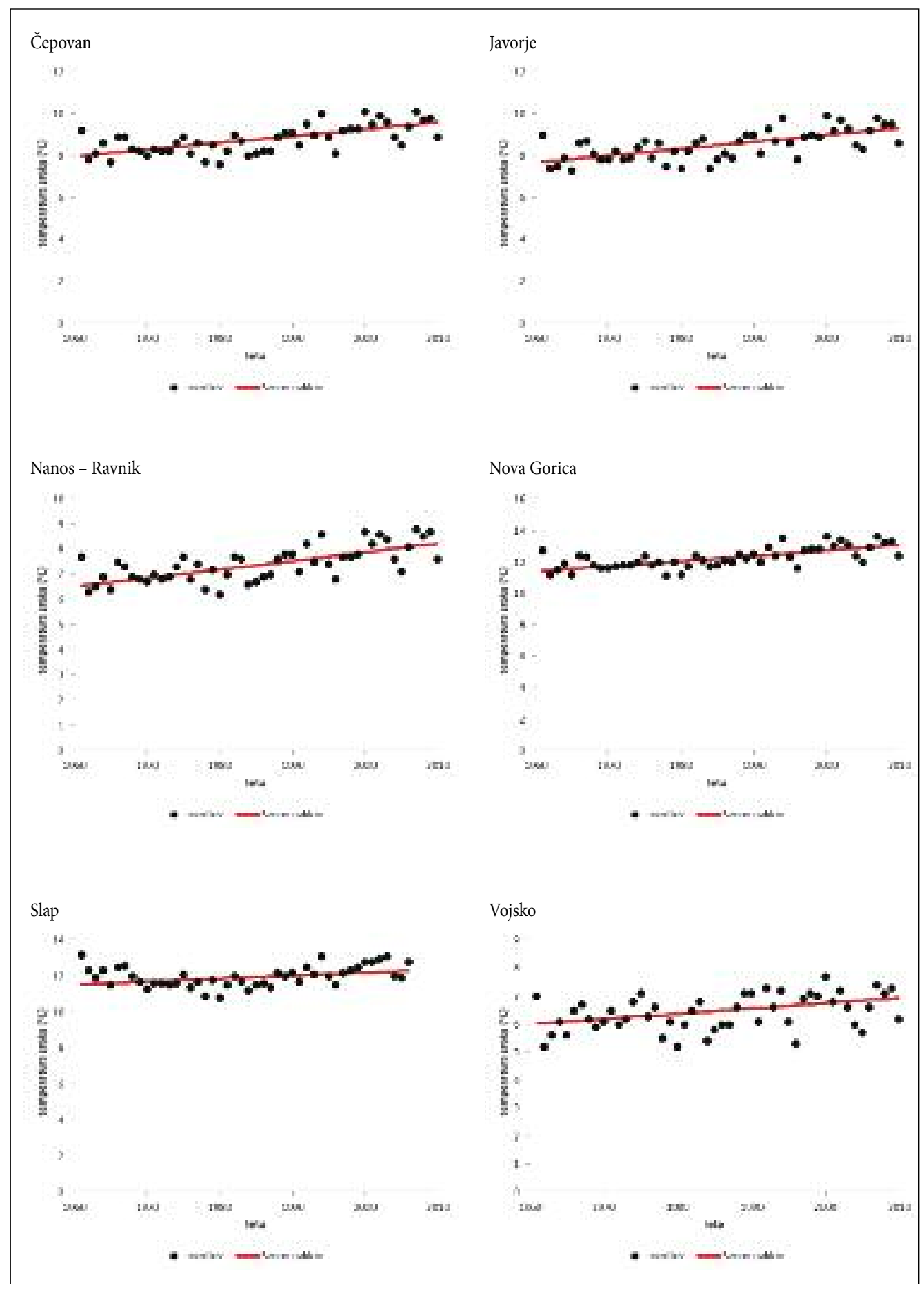


Vrhnika

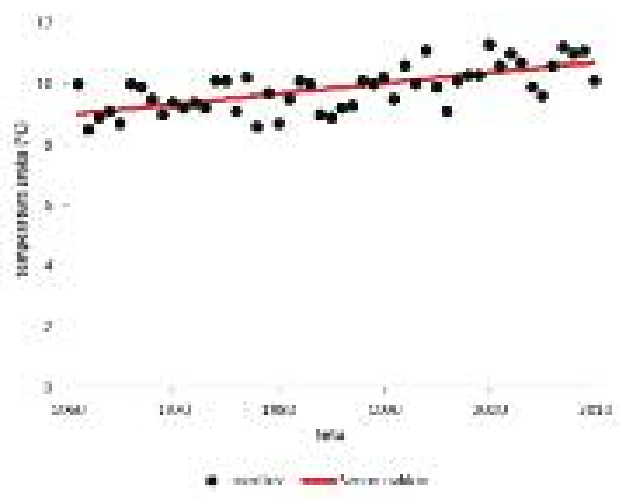

Slika 2: Trendi povprečnih letnih temperatur $\left(v^{\circ} \mathrm{C}\right)$ v obdobju od 1961 do 2010.

kar pomeni, da se je v zadnjega pol stoletja na omenjenih postajah količina padavin znižala za $235-565 \mathrm{~mm}$ oziroma za 10-20\%. Absolutna razlika količine padavin v obdobju od 1961 do 2010 je največja na postaji Mrzla Rupa, kjer je količina padavin upadla za $565,0 \mathrm{~mm}$, relativna razlika pa je največja na postajah Otlica in Na stanu (Šebreljski Vrh), ki beležita upad padavin za 20,2 \%.

Nekoliko manjše upadanje količine padavin beležita le postaji Hotedršica in Idrija. V Hotedršici se je v obravnavanem polstoletnem obdobju količina padavin znižala za 74,3 mm (3,9\%), v Idriji pa za 235,0 mm (9,9\%). Upad padavin v Idriji je le neznatno manjši od povprečja za širše idrijsko območje in je verjetno posledica nekoliko krajšega podatkovnega niza (1961-1999).

Preglednica 5: Trendi količine letnih padavin v obdobju od 1961 do 2010.

\begin{tabular}{lccccccc}
\hline $\begin{array}{l}\text { padavinska } \\
\text { postaja }\end{array}$ & $\begin{array}{c}\text { Mann- } \\
\text { Kendallov } \\
\text { test }\end{array}$ & $\begin{array}{c}\text { raven } \\
\text { zaupanja }\end{array}$ & $\begin{array}{c}\text { Senov } \\
\text { naklon }\end{array}$ & $\begin{array}{c}\text { trendno } \\
\text { stanje } \\
1961\end{array}$ & $\begin{array}{c}\text { trendno } \\
\text { stanje } \\
2010\end{array}$ & $\begin{array}{c}\text { trendna } \\
\text { razlika } \\
1961-2010\end{array}$ & $\begin{array}{c}\text { trendna } \\
\text { razlika } \\
1961-2010\end{array}$ \\
\hline & $\mathrm{Z}$ & $\%$ & $\mathrm{Q}$ & $\mathrm{mm}$ & $\mathrm{mm}$ & $\mathrm{mm}$ & $\%$ \\
\hline Crni Vrh & $-1,84$ & 90,0 & $-5,869$ & 2678,14 & 2384,70 & $-293,44$ & $-10,96$ \\
Hotedršica & $-0,54$ & pod 90,0 & $-1,486$ & 1929,60 & 1855,28 & $-74,32$ & $-3,85$ \\
Idrija & $-1,10$ & pod 90,0 & $-4,699$ & 2363,38 & 2128,42 & $-234,96$ & $-9,94$ \\
Logatec & $-2,51$ & 95,0 & $-6,571$ & 2031,12 & 1702,57 & $-328,55$ & $-16,18$ \\
Mrzla Rupa & $-2,66$ & 99,0 & $-11,300$ & 2983,80 & 2418,80 & $-565,00$ & $-18,94$ \\
Na stanu & $-2,82$ & 99,0 & $-8,333$ & 2059,61 & 1642,98 & $-416,63$ & $-20,23$ \\
Otlica & $-2,58$ & 99,0 & $-10,367$ & 2569,48 & 2051,15 & $-518,33$ & $-20,17$ \\
Slap & $-2,46$ & 95,0 & $-5,881$ & 1609,34 & 1315,30 & $-294,04$ & $-18,27$ \\
Vojsko & $-2,59$ & 99,0 & $-9,000$ & 2597,30 & 2147,30 & $-450,00$ & $-17,33$ \\
\hline
\end{tabular}




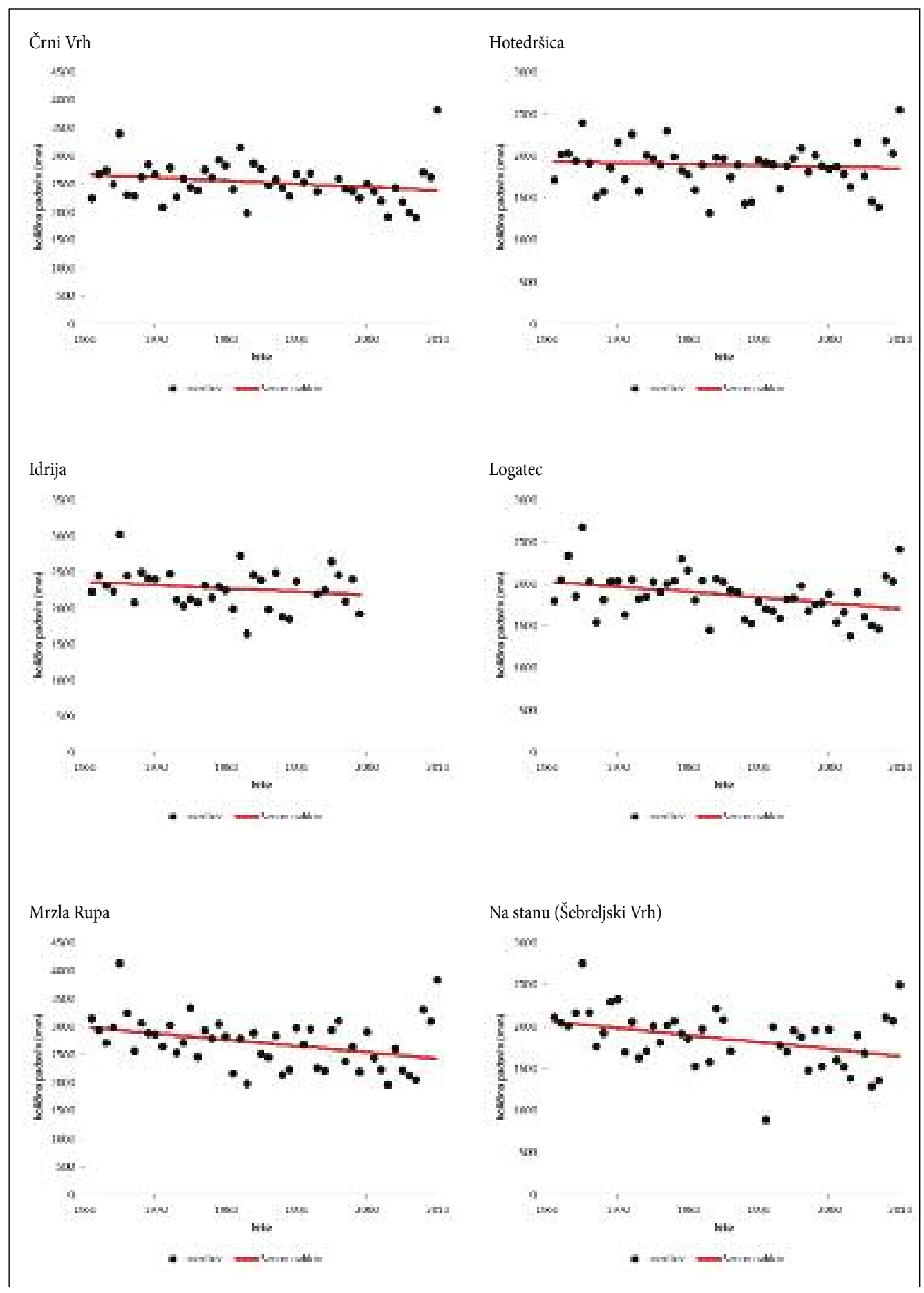




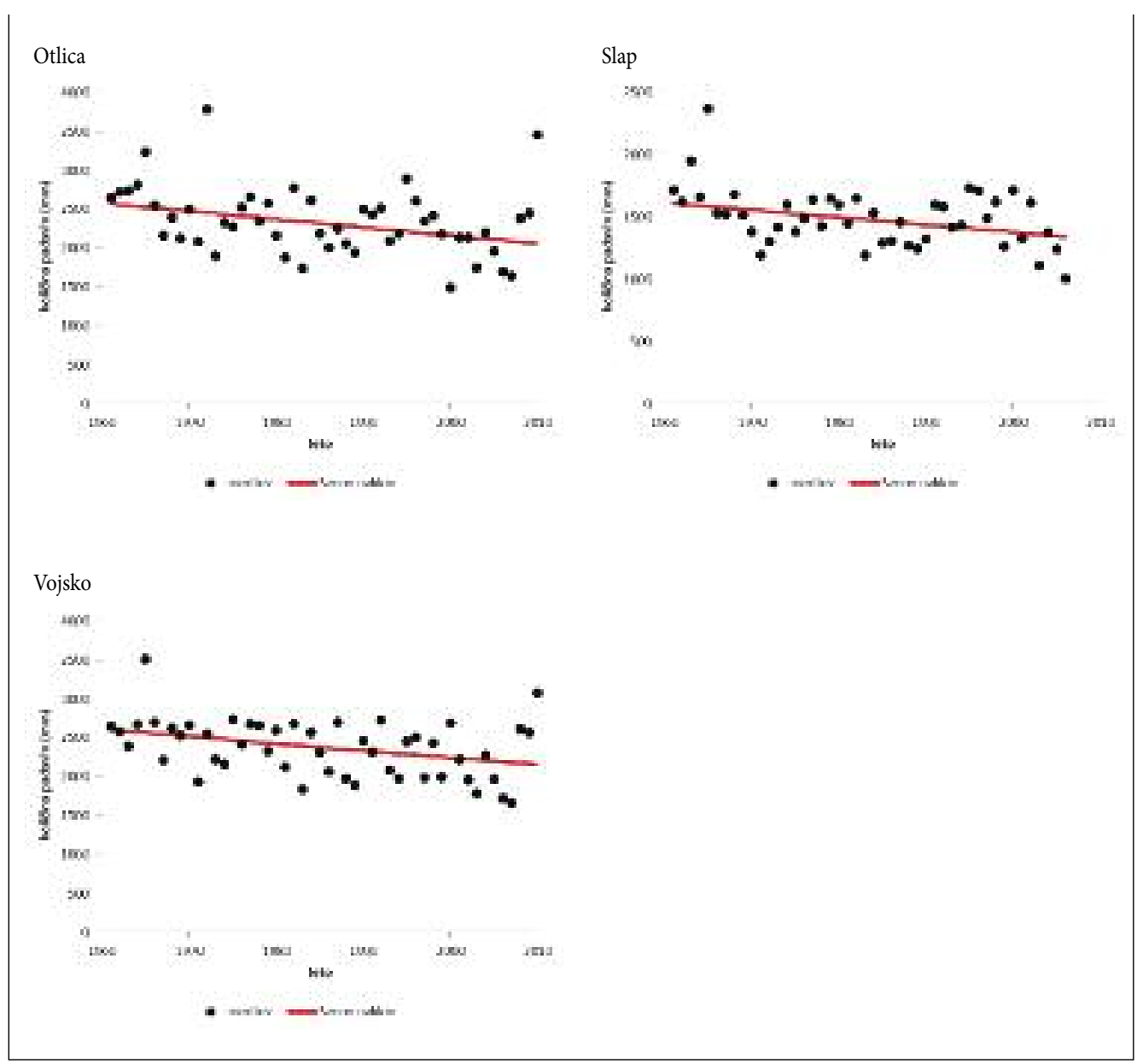

Slika 3: Trendi količine letnih padavin $(v \mathrm{~mm})$ v obdobju od 1961 do 2010. 


\subsubsection{Letno število dni s padavinami nad $0,1 \mathrm{~mm}$}

Ker smo na vseh devetih padavinskih postajah ugotovili zmanjšanje količine padavin, nas je zanimalo, ali se je v istem obdobju zmanjšalo tudi število dni s padavinami nad $0,1 \mathrm{~mm}$. Presenetljivo je, da se je v obdobju od 1961 do 2010 število padavinskih dni na šestih obravnavanih padavinskih postajah celo povečalo, upadanje pa beležijo le tri padavinske postaje (preglednica 6 , slika 4). Značilna je tudi izredno nizka raven zaupanja, ki kar na osmih od devetih postajah ne presega $90 \%$. Izjemo predstavlja le padavinska postaja Idrija, ki ima nekoliko višjo raven zaupanja (95\%), morda zaradi krajšega podatkovnega niza (1961-1999).

Absolutna in relativna pozitivna razlika v številu padavinskih dni v obdobju od 1961 do 2010 je največja na postaji Otlica, kjer je število padavinskih dni naraslo za 16,2 dni oziroma za 12,0 \%, absolutna in relativna negativna razlika v številu padavinskih dni pa je največja na postaji Idrija, kjer je število padavinskih dni upadlo za 29,2 dni oziroma za $17,9 \%$.

Omeniti velja, da so tako pozitivne kot negativne razlike v številu padavinskih dni povečini majhne in na šestih od devetih obravnavanih postajah (Črni Vrh, Hotedršica, Logatec, Mrzla Rupa, Na stanu (Šebreljski Vrh) in Vojsko) ne dosegajo niti $10 \%$.

Preglednica 6: Trendi števila dni s padavinami na leto v obdobju od 1961 do 2010.

\begin{tabular}{lcccccrr}
\hline $\begin{array}{l}\text { padavinska } \\
\text { postaja }\end{array}$ & $\begin{array}{c}\text { Mann- } \\
\text { Kendallov } \\
\text { test }\end{array}$ & $\begin{array}{c}\text { raven } \\
\text { zaupanja }\end{array}$ & $\begin{array}{c}\text { Senov } \\
\text { naklon }\end{array}$ & $\begin{array}{c}\text { trendno } \\
\text { stanje } \\
1961\end{array}$ & $\begin{array}{c}\text { trendno } \\
\text { stanje } \\
2010\end{array}$ & $\begin{array}{c}\text { trendna } \\
\text { razlika } \\
1961-2010\end{array}$ & $\begin{array}{c}\text { trendna } \\
\text { razlika } \\
1961-2010\end{array}$ \\
\hline & $\mathrm{Z}$ & $\%$ & $\mathrm{Q}$ & število & število & število & $\%$ \\
\hline Črni Vrh & 0,329 & $\operatorname{pod} 90,0$ & 0,077 & 147,15 & 151,00 & 3,85 & 2,62 \\
Hotedršica & 0,937 & $\operatorname{pod} 90,0$ & 0,176 & 140,00 & 148,82 & 8,82 & 6,30 \\
Idrija & $-2,045$ & 95,0 & $-0,583$ & 162,67 & 133,50 & $-29,17$ & $-17,93$ \\
Logatec & $-0,427$ & $\operatorname{pod} 90,0$ & $-0,067$ & 151,63 & 148,30 & $-3,33$ & $-2,20$ \\
Mrzla Rupa & 1,306 & $\operatorname{pod} 90,0$ & 0,238 & 129,71 & 141,62 & 11,91 & 9,18 \\
Na stanu & 1,308 & $\operatorname{pod} 90,0$ & 0,237 & 129,84 & 141,68 & 11,84 & 9,12 \\
Otlica & 1,415 & $\operatorname{pod} 90,0$ & 0,324 & 134,46 & 150,63 & 16,17 & 12,03 \\
Slap & $-1,536$ & $\operatorname{pod} 90,0$ & $-0,292$ & 139,19 & 124,60 & $-14,59$ & $-10,48$ \\
Vojsko & 1,875 & 90,0 & 0,289 & 149,54 & 164,01 & 14,47 & 9,68 \\
\hline
\end{tabular}




\subsubsection{Letno število dni s snežno odejo}

Od podnebnih kazalnikov nas je zanimalo še število dni s snežno odejo, saj so v zadnjih desetletjih zime toplejše in snežna odeja bolj skromna. Naše domneve so trendi potrdili, saj so na osmih od devetih obravnavanih padavinskih postajah padajoči (preglednica 7, slika 5).

Raven zaupanja je spremenljiva. Na štirih postajah (Idrija, Mrzla Rupa, Otlica in Slap) ne dosega niti $90 \%$, na postaji Na stanu (Šebreljski Vrh) je $95 \%$, na preostalih štirih postajah (Črni Vrh, Hotedršica, Logatec in Vojsko) pa $99 \%$.

V obravnavanem obdobju (1961-2010) je število dni s snežno odejo na sedmih od devetih upoštevanih padavinskih postajah upadlo za 21 do 43 dni oziroma za 22 do $46 \%$. Za več kot dvajset dni letno se je obdobje s snežno odejo skrajšalo na postajah Mrzla Rupa in Otlica, za trideset dni in več na postajah Črni Vrh, Na stanu (Šebreljski Vrh) in Vojsko ter za več kot štirideset dni na postajah Hotedršica in Logatec. Absolutna in relativna negativna razlika $v$ številu dni s snežno odejo je največja na postaji Logatec, kjer je število dni s snežno odejo upadlo za 42,9 dni oziroma za 46,4\%.

Zelo skromen upad števila dni s snežno odejo je zabeležen v Idriji (le 1,4 dneva oziroma 2,1 \%), vendar domnevamo, da je to posledica krajšega podatkovnega niza (1961-1999). Edina postaja, ki nima padajočega trenda števila dni s snežno odejo, je presenetljivo Slap v Vipavski dolini. Zaradi sredozemskega podnebja in nizke nadmorske višine na tej postaji tudi v preteklosti niso beležili dolgotrajne in debelejše snežne odeje.

Preglednica 7: Trendi števila dni s snežno odejo na leto v obdobju od 1961 do 2010.

\begin{tabular}{lccccrrr}
\hline $\begin{array}{l}\text { padavinska } \\
\text { postaja }\end{array}$ & $\begin{array}{c}\text { Mann- } \\
\text { Kendallov } \\
\text { test }\end{array}$ & $\begin{array}{c}\text { raven } \\
\text { zaupanja }\end{array}$ & $\begin{array}{c}\text { Senov } \\
\text { naklon }\end{array}$ & $\begin{array}{c}\text { trendno } \\
\text { stanje } \\
1961\end{array}$ & $\begin{array}{c}\text { trendno } \\
\text { stanje } \\
2010\end{array}$ & $\begin{array}{c}\text { trendna } \\
\text { razlika } \\
1961-2010\end{array}$ & $\begin{array}{c}\text { trendna } \\
\text { razlika } \\
1961-2010\end{array}$ \\
\hline & $\mathrm{Z}$ & $\%$ & $\mathrm{Q}$ & število & število & število & $\%$ \\
\hline Črni Vrh & $-2,703$ & 99,0 & $-0,770$ & 104,24 & 65,75 & $-38,49$ & $-36,92$ \\
Hotedršica & $-2,820$ & 99,0 & $-0,836$ & 106,03 & 64,23 & $-41,80$ & $-39,42$ \\
Idrija & $-0,041$ & pod 90,0 & $-0,028$ & 65,56 & 64,17 & $-1,39$ & $-2,12$ \\
Logatec & $-2,820$ & 99,0 & $-0,857$ & 92,43 & 49,57 & $-42,86$ & $-46,37$ \\
Mrzla Rupa & $-1,398$ & pod 90,0 & $-0,500$ & 112,00 & 87,00 & $-25,00$ & $-22,32$ \\
Na stanu & $-2,112$ & 95,0 & $-0,600$ & 106,00 & 76,00 & $-30,00$ & $-28,30$ \\
Otlica & $-1,288$ & pod 90,0 & $-0,426$ & 71,06 & 49,79 & $-21,27$ & $-29,93$ \\
Slap & $-0,507$ & pod 90,0 & 0,000 & 3,00 & 3,00 & 0,00 & 0,00 \\
Vojsko & $-2,854$ & 99,0 & $-0,765$ & 151,68 & 114,21 & $-37,47$ & $-24,70$ \\
\hline
\end{tabular}



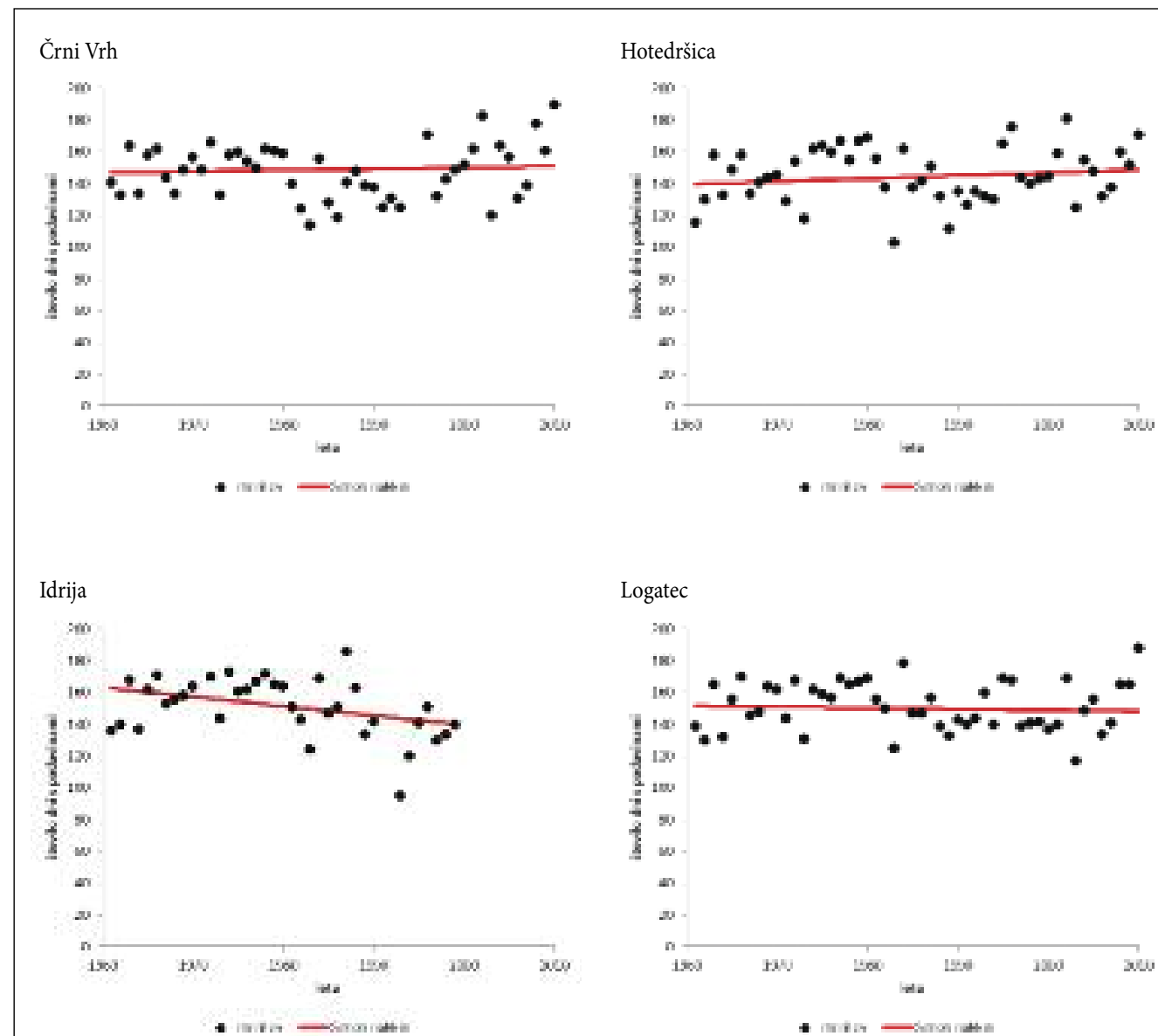

Mrzla Rupa

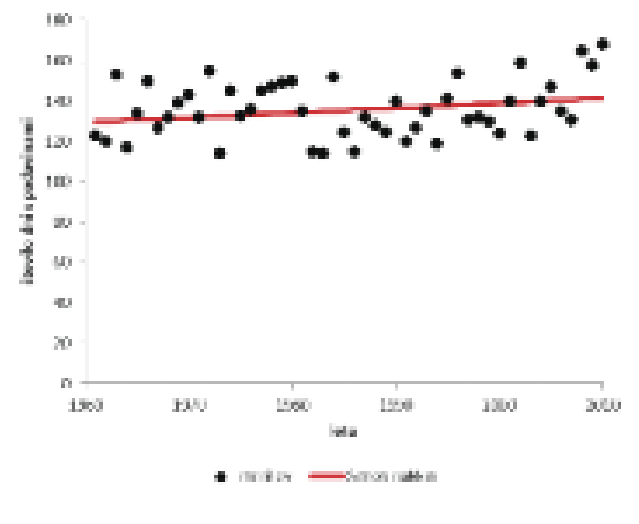

Na stanu (Šebreljski Vrh)

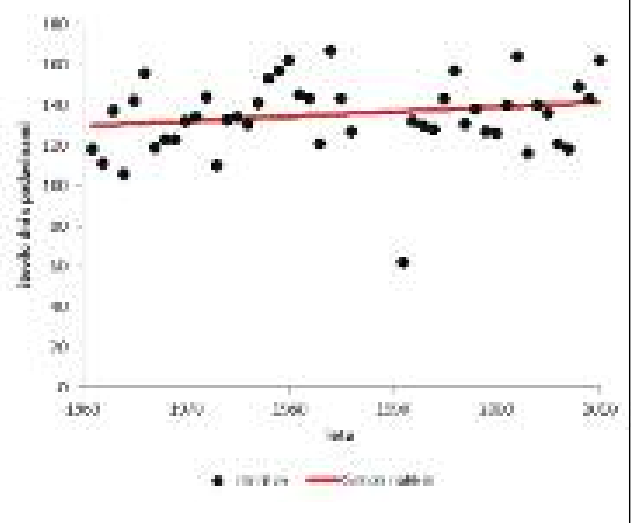



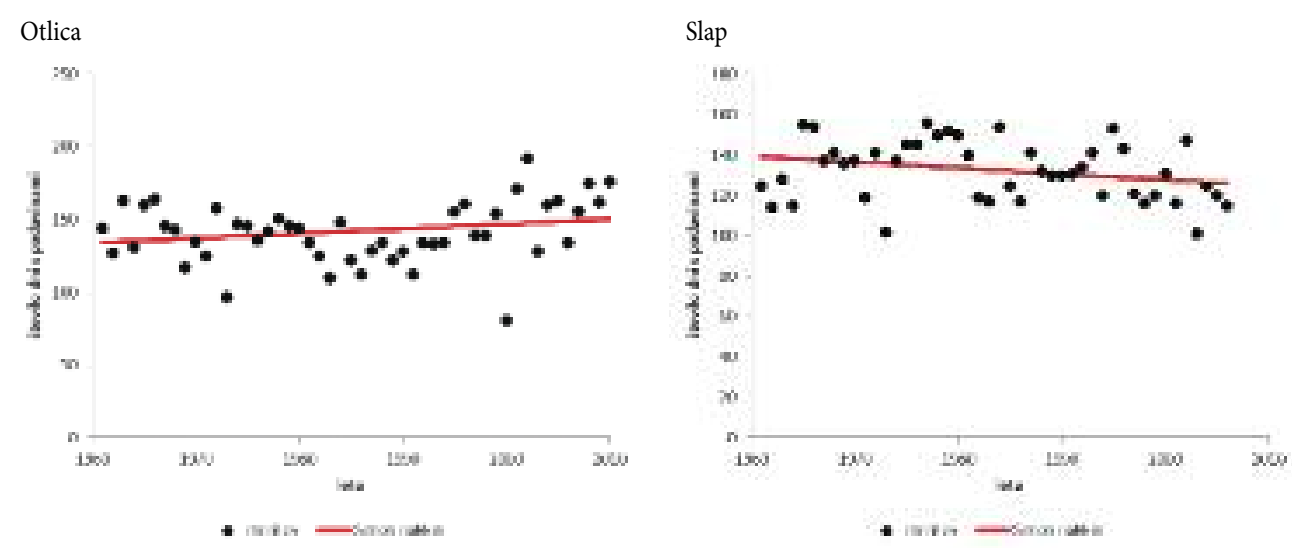

Vojsko

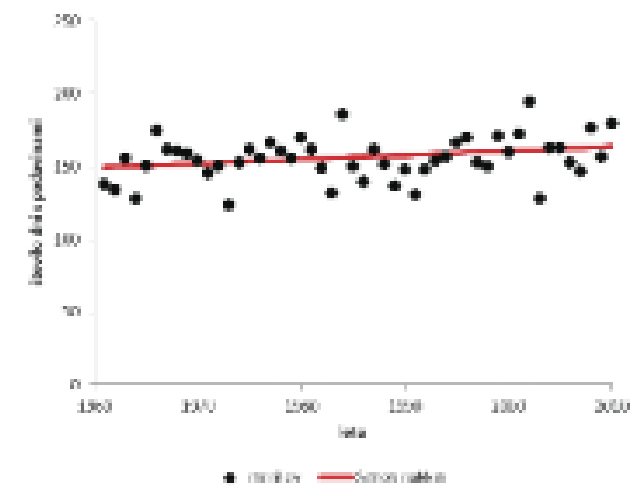

Slika 4: Trendi števila dni s padavinami na leto v obdobju od 1961 do 2010. 

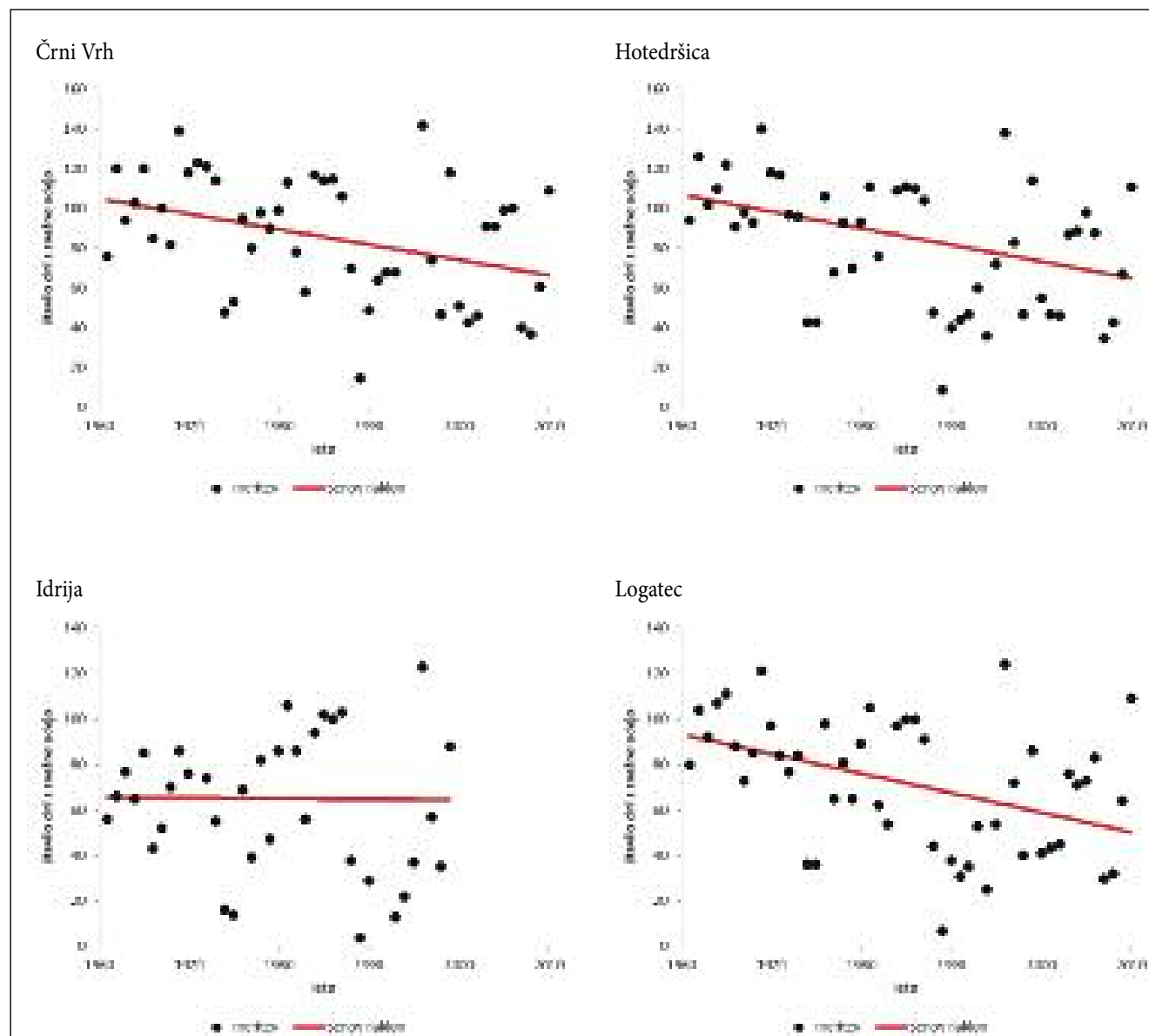

Logatec

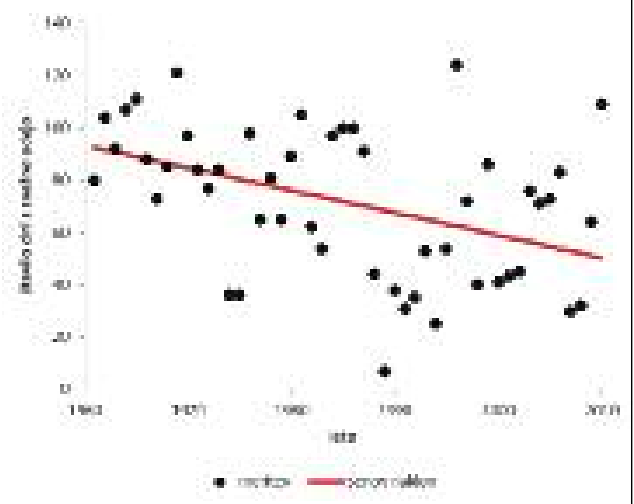

Mrzla Rupa

Na stanu (Šebreljski Vrh)
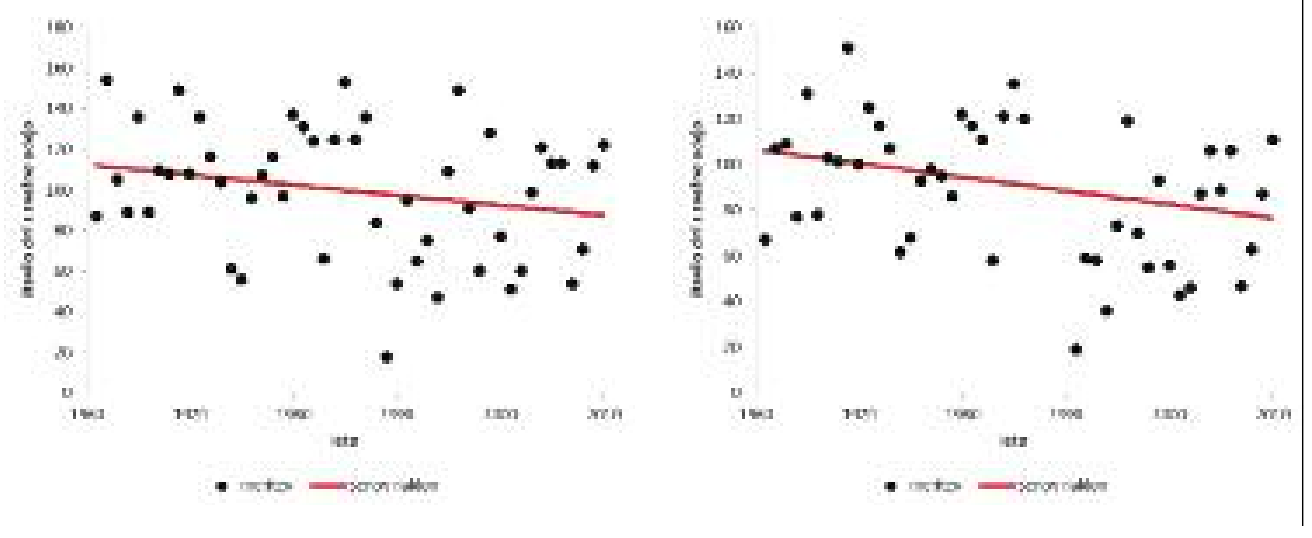


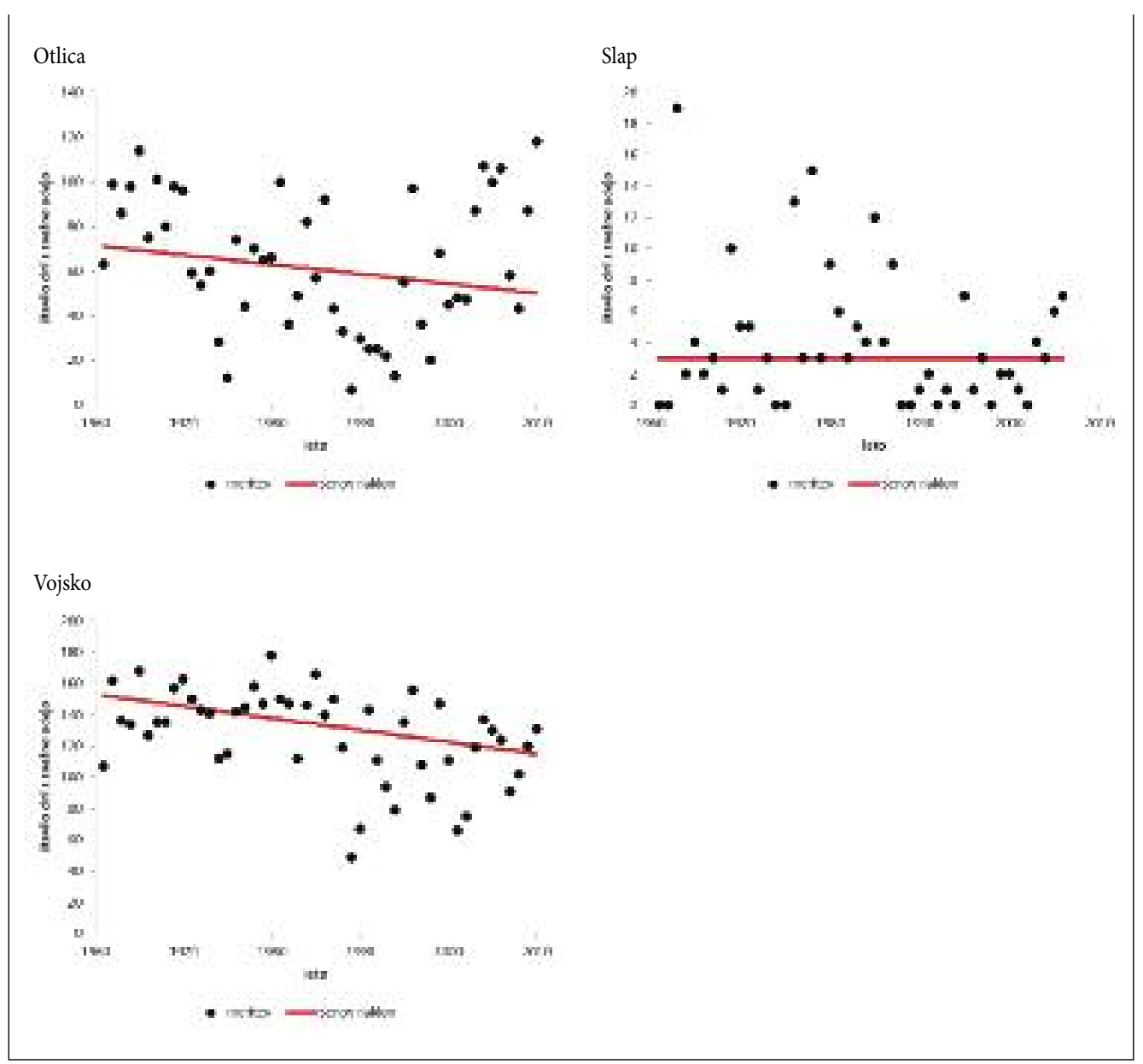

Slika 5: Trendi števila dni s snežno odejo na leto v obdobju od 1961 do 2010. 


\subsection{Hidrološke spremenljivke}

V okviru hidroloških spremenljivk smo obravnavali (preglednica 1): (1) trende absolutnih minimalnih letnih pretokov, (2) trende povprečnih minimalnih letnih pretokov, (3) trende povprečnih srednjih letnih pretokov, (4) trende povprečnih maksimalnih letnih pretokov in (5) trende absolutnih maksimalnih letnih pretokov.

\subsubsection{Absolutni minimalni letni pretoki}

Trendi absolutnih minimalnih letnih pretokov v obdobju od 1961 do 2010 so na petih vodotokih oziroma vodomernih postajah (v. p.) s popolnim nizom podatkov padajoči (preglednica 8, slika 6). Odstopata pa rezultata na Hotenjki (v. p. Hotedršica) in Idrijci (v. p. Reka), ki sta bila pridobljena na temelju krajšega, nepopolnega niza podatkov (1961-1985 na v. p. Hotedršica in 1961-1989 na v. p. Reka).

Raven zaupanja je precej spremenljiva. Najnižja je na obeh vodomernih postajah na Idrijci (v. p. Podroteja in v. p. Reka), kjer ne dosega $90 \%$, najvišja pa na Cerknici (v. p. Cerkno), Hublju (v. p. Ajdovščina) in Poljanski Sori (v. p. Žiri), kjer dosega kar 99,9\%.

Že tako skromni absolutni minimalni pretoki so se v obravnavanem obdobju (1961-2010) zmanjšali za 0,09 do $0,36 \mathrm{~m}^{3} / \mathrm{s}$ oziroma za 90 do $360 \mathrm{l} / \mathrm{s}$. V relativnem smislu beleži večina vodotokov upad od 17,3 do 50,0\%. Tako v absolutnem kot relativnem smislu beleži največji upad rečica Hubelj v Ajdovščini, katere absolutni minimalni pretok se je v obdobju od 1961 do 2010 zmanjšal za $0,37 \mathrm{~m}^{3} / \mathrm{s}$ oziroma za $77 \%$.

V nasprotju z vsemi ostalimi vodotoki so se absolutni minimalni pretoki Hotenjke pri Hotedršici celo povečali, a je povečanje vodnatosti $\mathrm{v}$ absolutnem smislu dejansko zelo skromno $\left(0,04 \mathrm{~m}^{3} / \mathrm{s}\right)$ in ga lahko kljub izredno visoki relativni vrednosti (kar $400 \%$ ) zanemarimo.

Preglednica 8: Trendi absolutnih minimalnih letnih pretokov v obdobju od 1961 do 2010.

\begin{tabular}{|c|c|c|c|c|c|c|c|c|}
\hline $\begin{array}{l}\text { vodomerna } \\
\text { postaja }\end{array}$ & vodotok & $\begin{array}{l}\text { Mann- } \\
\text { Kendallov } \\
\text { test }\end{array}$ & $\begin{array}{c}\text { raven } \\
\text { zaupanja }\end{array}$ & $\begin{array}{l}\text { Senov } \\
\text { naklon }\end{array}$ & $\begin{array}{c}\text { trendno } \\
\text { stanje } \\
1961\end{array}$ & $\begin{array}{c}\text { trendno } \\
\text { stanje } \\
2010\end{array}$ & $\begin{array}{c}\text { trendna } \\
\text { razlika } \\
1961-2010\end{array}$ & $\begin{array}{c}\text { trendna } \\
\text { razlika } \\
1961-2010\end{array}$ \\
\hline & & Z & $\%$ & Q & $\mathrm{m}^{3} / \mathrm{s}$ & $\mathrm{m}^{3} / \mathrm{s}$ & $\mathrm{m}^{3} / \mathrm{s}$ & $\%$ \\
\hline Podroteja & Idrijca & $-1,39$ & pod 90,0 & $-0,006$ & 1,68 & 1,39 & $-0,29$ & $-17,26$ \\
\hline Žiri & $\begin{array}{l}\text { Poljanska } \\
\text { Sora }\end{array}$ & $-3,57$ & 99,9 & $-0,003$ & 0,37 & 0,20 & $-0,17$ & $-45,95$ \\
\hline Hotedršica & Hotenjka & 2,50 & 95,0 & 0,001 & 0,01 & 0,05 & 0,04 & 400,00 \\
\hline Reka & Idrijca & $-0,06$ & $\operatorname{pod} 90,0$ & $-0,002$ & 3,74 & 3,65 & $-0,09$ & $-2,41$ \\
\hline Cerkno & Cerknica & $-3,71$ & 99,9 & $-0,004$ & 0,46 & 0,23 & $-0,23$ & $-50,00$ \\
\hline $\begin{array}{l}\text { Dolenja } \\
\text { Trebuša }\end{array}$ & Trebuščica & $-2,01$ & 95,0 & $-0,004$ & 0,68 & 0,49 & $-0,19$ & $-27,94$ \\
\hline Ajdovščina & Hubelj & $-6,24$ & 99,9 & $-0,007$ & 0,48 & 0,11 & $-0,37$ & $-77,08$ \\
\hline
\end{tabular}




\subsubsection{Povprečni minimalni letni pretoki}

Trendi povprečnih minimalnih letnih pretokov v obdobju od 1961 do 2010 so na vseh petih vodotokih oziroma vodomernih postajah s popolnim nizom podatkov padajoči (preglednica 9, slika 7). Poleg tega ima padajoč trend tudi Idrijca na v. p. Reka, medtem ko je trend Hotenjke na v. p. Hotedršica celo rahlo naraščajoč.

Raven zaupanja je tudi v tem primeru močno spremenljiva. Najnižja je pri Hotenjki (v. p. Hotedršica) in Idrijci (v. p. Reka), kjer ne dosega 90 \%. Obe postaji imata krajši podatkovni niz (1961-1985 na v. p. Hotedršica in 1961-1989 na v. p. Reka). Najvišjo raven zaupanja ima Poljanska Sora (v. p. Žiri), ki dosega kar 99,9\%.

Povprečni minimalni pretoki so se v obravnavanem obdobju (1961-2010) zmanjšali za 0,21 do $1,60 \mathrm{~m}^{3} / \mathrm{s}$. V relativnem smislu beleži večina vodotokov upad od 17,2 do $36,1 \%$. Absolutna razlika povprečnih minimalnih pretokov v obdobju od 1961 do 2010 je največja na Idrijci pri v. p. Reka, kjer je pretok upadel za $1,6 \mathrm{~m}^{3} / \mathrm{s}$, relativna razlika pa je največja na Poljanski Sori pri Žireh, ki beleži upad povprečnega minimalnega pretoka za $36,1 \%$.

Podobno kot pri absolutnih minimalnih pretokih tudi pri povprečnih minimalnih pretokih izstopa Hotenjka (v. p. Hotedršica), ki v obravnavanem obdobju edina beleži porast. A tudi v tem primeru je povečanje vodnatosti $v$ absolutnem smislu skromno $\left(0,01 \mathrm{~m}^{3} / \mathrm{s}\right)$ in ga lahko zanemarimo, saj je možno, da je posledica ne povsem zanesljivih meritev.

Preglednica 9: Trendi povprečnih minimalnih letnih pretokov v obdobju od 1961 do 2010.

\begin{tabular}{|c|c|c|c|c|c|c|c|c|}
\hline $\begin{array}{l}\text { vodomerna } \\
\text { postaja }\end{array}$ & vodotok & $\begin{array}{l}\text { Mann- } \\
\text { Kendallov } \\
\text { test }\end{array}$ & $\begin{array}{c}\text { raven } \\
\text { zaupanja }\end{array}$ & $\begin{array}{l}\text { Senov } \\
\text { naklon }\end{array}$ & $\begin{array}{c}\text { trendno } \\
\text { stanje } \\
1961\end{array}$ & $\begin{array}{l}\text { trendno } \\
\text { stanje } \\
2010\end{array}$ & $\begin{array}{l}\text { trendna } \\
\text { razlika } \\
1961-2010\end{array}$ & $\begin{array}{c}\text { trendna } \\
\text { razlika } \\
1961-2010\end{array}$ \\
\hline & & Z & $\%$ & Q & $\mathrm{m}^{3} / \mathrm{s}$ & $\mathrm{m}^{3} / \mathrm{s}$ & $\mathrm{m}^{3} / \mathrm{s}$ & $\%$ \\
\hline Podroteja & Idrijca & $-1,76$ & 90,0 & $-0,009$ & 2,62 & 2,17 & $-0,45$ & $-17,18$ \\
\hline Žiri & $\begin{array}{l}\text { Poljanska } \\
\text { Sora }\end{array}$ & $-4,45$ & 99,9 & $-0,005$ & 0,61 & 0,39 & $-0,22$ & $-36,07$ \\
\hline Hotedršica & Hotenjka & 0,51 & pod 90,0 & 0,000 & 0,04 & 0,05 & 0,01 & 25,00 \\
\hline Reka & Idrijca & $-1,41$ & pod 90,0 & $-0,032$ & 7,32 & 5,72 & $-1,60$ & $-21,86$ \\
\hline Cerkno & Cerknica & $-2,94$ & 99,0 & $-0,006$ & 0,97 & 0,65 & $-0,32$ & $-32,99$ \\
\hline $\begin{array}{l}\text { Dolenja } \\
\text { Trebuša }\end{array}$ & Trebuščica & $-2,00$ & 95,0 & $-0,006$ & 1,27 & 0,97 & $-0,30$ & $-23,62$ \\
\hline Ajdovščina & Hubelj & $-1,80$ & 90,0 & $-0,004$ & 1,02 & 0,81 & $-0,21$ & $-20,59$ \\
\hline
\end{tabular}



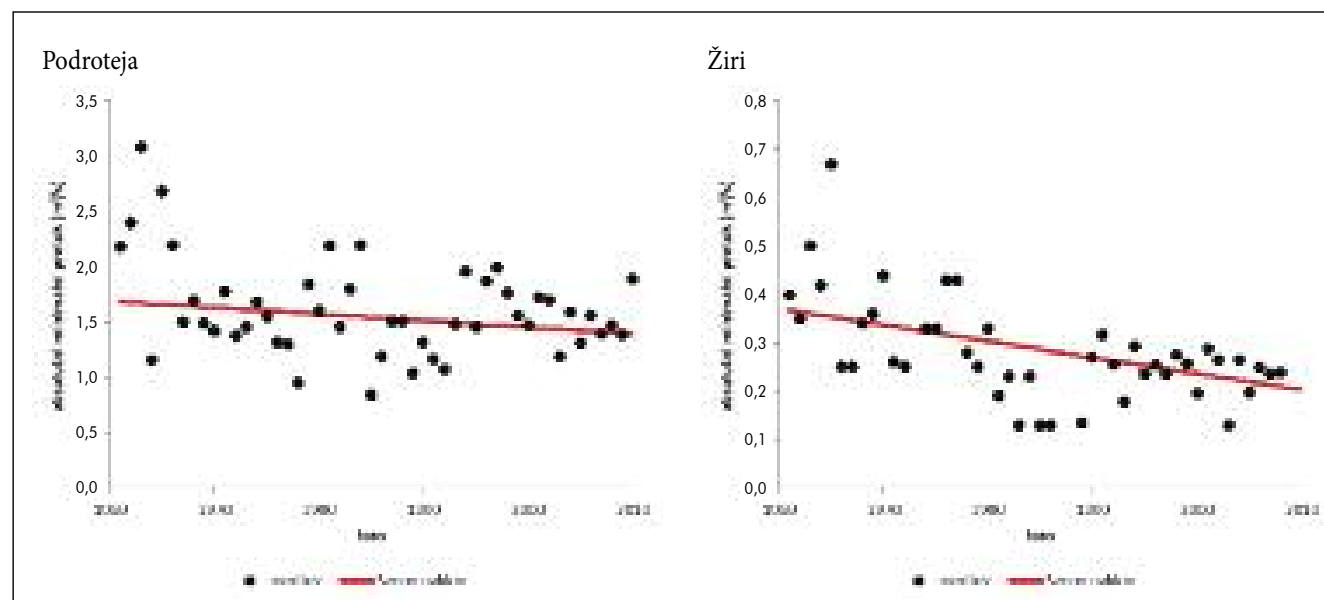

Hotedršica

Reka
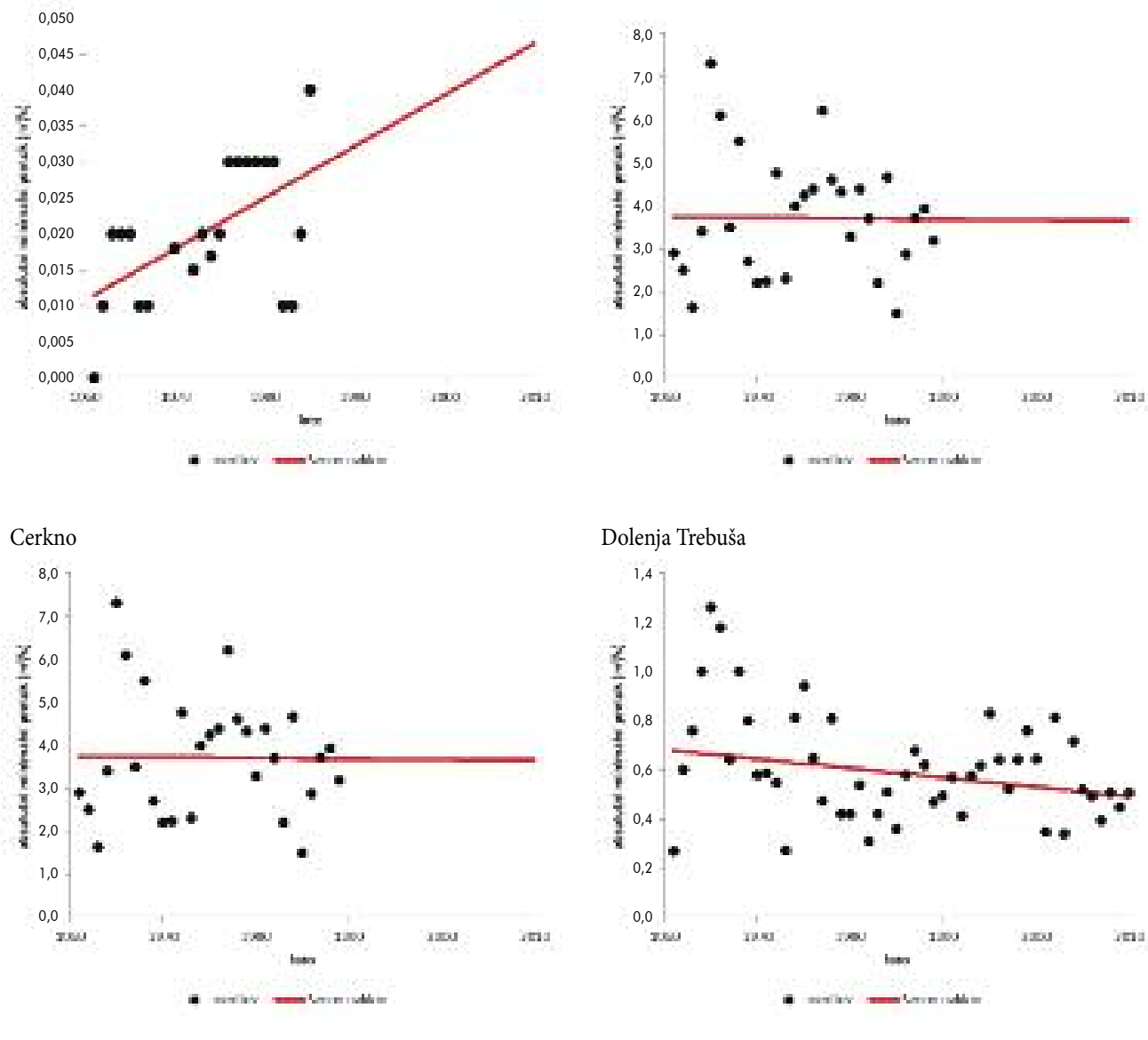

Dolenja Trebuša

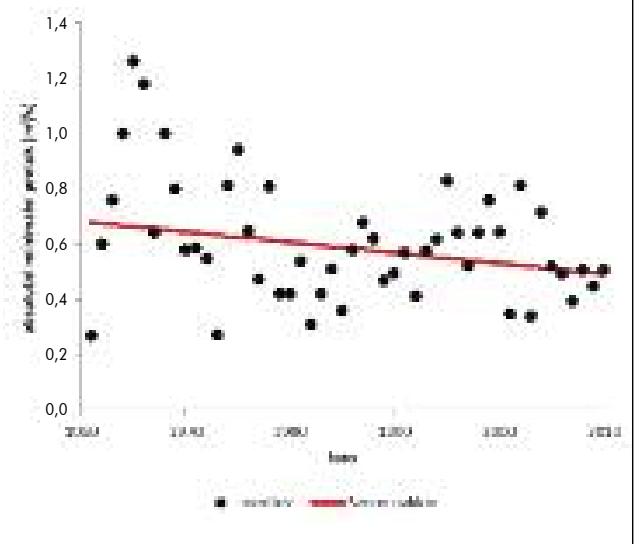




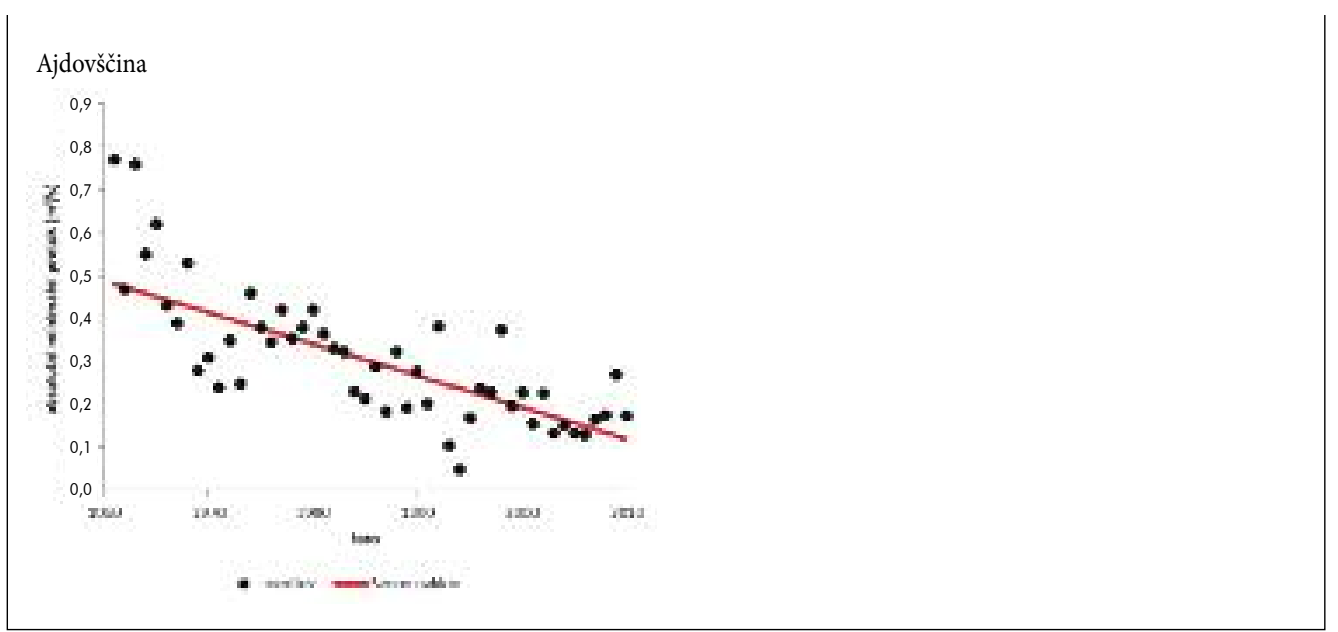

Slika 6: Trendi absolutnih minimalnih letnih pretokov $\left(\mathrm{v} \mathrm{m}^{3} / \mathrm{s}\right)$ v obdobju od 1961 do 2010. 


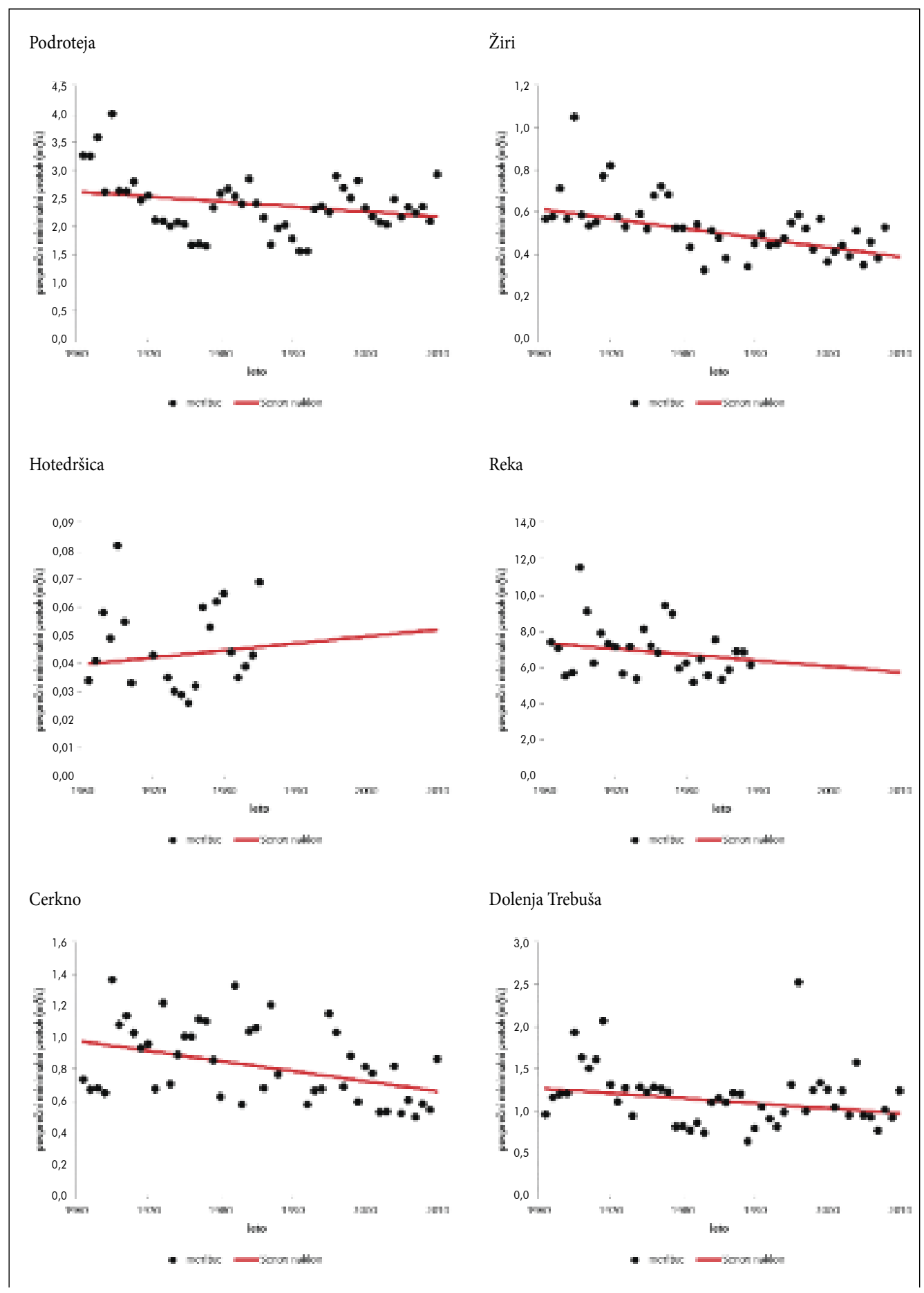




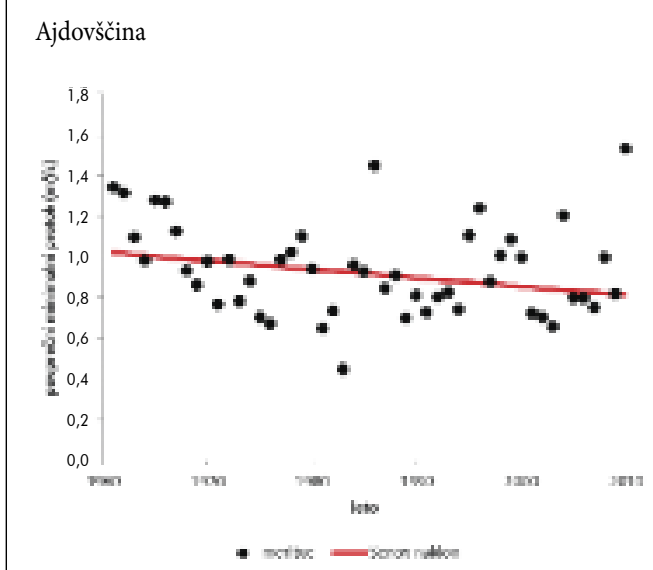

Slika 7: Trendi povprečnih minimalnih letnih pretokov $\left(v \mathrm{~m}^{3} / \mathrm{s}\right)$ v obdobju od 1961 do 2010. 


\subsubsection{Povprečni srednji letni pretoki}

Trendi povprečnih srednjih letnih pretokov v obdobju od 1961 do 2010 so na vseh sedmih vodotokih oziroma vodomernih postajah padajoči (preglednica 10, slika 8). Raven zaupanja je zelo visoka, saj je na šestih obravnavanih vodotokih oziroma vodomernih postajah vsaj $99 \%$. Zaradi krajšega in verjetno manj zanesljivega podatkovnega niza je nižja raven zaupanja samo pri Hotenjki na v. p. Hotedršica $(90 \%)$.

Srednji letni pretoki so se v obravnavanem obdobju (1961-2010) na vodotokih s popolnim nizom podatkov zmanjšali za $0,68 \mathrm{do} 3,43 \mathrm{~m}^{3} / \mathrm{s}$. V relativnem smislu beleži večina vodotokov upad od 23,2 do 33,5\%. Absolutna in relativna trendna razlika povprečnih srednjih pretokov v obdobju od 1961 do 2010 je največja na Idrijci pri v. p. Podroteja, kjer je pretok upadel za $3,43 \mathrm{~m}^{3} / \mathrm{s}$ oziroma za $33,1 \%$.

Še večji upad je zabeležen na Idrijci pri v. p. Reka $\left(-13,22 \mathrm{~m}^{3} / \mathrm{s}\right.$ oziroma $\left.-60,8 \%\right)$ in Hotenjki pri v. p. Hotedršica $\left(-0,23 \mathrm{~m}^{3} / \mathrm{s}\right.$ oziroma $\left.-85,2 \%\right)$, vendar so te trendne razlike ugotovljene na temelju krajšega podatkovnega niza (1961-1989 na v. p. Reka in 1961-1985 na v. p. Hotedršica).

Preglednica 10: Trendi povprečnih srednjih letnih pretokov v obdobju od 1961 do 2010.

\begin{tabular}{|c|c|c|c|c|c|c|c|c|}
\hline $\begin{array}{l}\text { vodomerna } \\
\text { postaja }\end{array}$ & vodotok & $\begin{array}{l}\text { Mann- } \\
\text { Kendallov } \\
\text { test }\end{array}$ & $\begin{array}{c}\text { raven } \\
\text { zaupanja }\end{array}$ & $\begin{array}{l}\text { Senov } \\
\text { naklon }\end{array}$ & $\begin{array}{c}\text { trendno } \\
\text { stanje } \\
1961\end{array}$ & $\begin{array}{c}\text { trendno } \\
\text { stanje } \\
2010\end{array}$ & $\begin{array}{c}\text { trendna } \\
\text { razlika } \\
1961-2010\end{array}$ & $\begin{array}{c}\text { trendna } \\
\text { razlika } \\
1961-2010\end{array}$ \\
\hline & & Z & $\%$ & Q & $\mathrm{m}^{3} / \mathrm{s}$ & $\mathrm{m}^{3} / \mathrm{s}$ & $\mathrm{m}^{3} / \mathrm{s}$ & $\%$ \\
\hline Podroteja & Idrijca & $-3,438$ & 99,9 & $-0,069$ & 10,35 & 6,92 & $-3,43$ & $-33,14$ \\
\hline Žiri & $\begin{array}{l}\text { Poljanska } \\
\text { Sora }\end{array}$ & $-2,984$ & 99,0 & $-0,015$ & 2,70 & 1,97 & $-0,73$ & $-27,04$ \\
\hline Hotedršica & Hotenjka & $-1,777$ & 90,0 & $-0,005$ & 0,27 & 0,04 & $-0,23$ & $-85,19$ \\
\hline Reka & Idrijca & $-3,433$ & 99,9 & $-0,264$ & 21,74 & 8,52 & $-13,22$ & $-60,81$ \\
\hline Cerkno & Cerknica & $-3,276$ & 99,0 & $-0,014$ & 2,03 & 1,35 & $-0,68$ & $-33,50$ \\
\hline $\begin{array}{l}\text { Dolenja } \\
\text { Trebuša }\end{array}$ & Trebuščica & $-3,480$ & 99,9 & $-0,019$ & 3,18 & 2,21 & $-0,97$ & $-30,50$ \\
\hline Ajdovščina & Hubelj & $-3,070$ & 99,0 & $-0,015$ & 3,32 & 2,55 & $-0,77$ & $-23,19$ \\
\hline
\end{tabular}




\subsubsection{Povprečni maksimalni letni pretoki}

Trendi povprečnih maksimalnih letnih pretokov v obdobju od 1961 do 2010 so na vseh sedmih vodotokih oziroma vodomernih postajah padajoči (preglednica 11, slika 9). Raven zaupanja je zelo visoka, saj je na petih obravnavanih vodotokih oziroma vodomernih postajah celo $99,9 \%$. Nižja je samo na Hotenjki pri v. p. Hotedršica (95\%) in na Poljanski Sori pri v. p. Žiri (pod $90 \%)$.

Povprečni maksimalni pretoki so se v obravnavanem obdobju (1961-2010) najbolj zmanjšali na reki Idrijci, ki po vodnatosti precej prekaša ostale upoštevane vodotoke. Na v. p. Podroteja je trendna razlika Idrijce $-32,80 \mathrm{~m}^{3} / \mathrm{s}$ oziroma $-52,0 \%$, na vodomerni postaji Reka pa $-84,67 \mathrm{~m}^{3} / \mathrm{s}$ oziroma $-78,5 \%$.

Precejšnje trendne razlike povprečnih maksimalnih pretokov so opazne tudi na Trebuščici pri v. p. Dolenja Trebuša $\left(-9,38 \mathrm{~m}^{3} / \mathrm{s}\right.$ oziroma $\left.-57,1 \%\right)$, na Hublju pri v. p. Ajdovščina $\left(-5,15 \mathrm{~m}^{3} / \mathrm{s}\right.$ oziroma $\left.-36,0 \%\right)$ in na Cerknici pri v. p. Cerkno $\left(-4,04 \mathrm{~m}^{3} / \mathrm{s}\right.$ oziroma $\left.-52,7 \%\right)$. Na rečici Hotenjki pri v. p. Hotedršica je zaradi intenzivnega upadanja povprečnih maksimalnih pretokov in kratkega podatkovnega niza (1961-1985) relativna trendna razlika dosegla nemogočo vrednost $-107,6 \%$.

Preglednica 11: Trendi povprečnih maksimalnih letnih pretokov v obdobju od 1961 do 2010.

\begin{tabular}{llccccccc}
\hline $\begin{array}{l}\text { vodomerna } \\
\text { postaja }\end{array}$ & vodotok & $\begin{array}{c}\text { Mann- } \\
\text { Kendallov } \\
\text { test }\end{array}$ & $\begin{array}{c}\text { raven } \\
\text { zaupanja }\end{array}$ & $\begin{array}{c}\text { Senov } \\
\text { naklon }\end{array}$ & $\begin{array}{c}\text { trendno } \\
\text { stanje } \\
1961\end{array}$ & $\begin{array}{c}\text { trendno } \\
\text { stanje } \\
2010\end{array}$ & $\begin{array}{c}\text { trendna } \\
\text { razlika } \\
1961-2010\end{array}$ & $\begin{array}{c}\text { trendna } \\
\text { razlika } \\
1961-2010\end{array}$ \\
\hline & & $\mathrm{Z}$ & $\%$ & $\mathrm{Q}$ & $\mathrm{m}^{3} / \mathrm{s}$ & $\mathrm{m}^{3} / \mathrm{s}$ & $\mathrm{m}^{3} / \mathrm{s}$ & $\%$ \\
\hline Podroteja & Idrijca & $-4,835$ & 99,9 & $-0,656$ & 63,09 & 30,29 & $-32,80$ & $-51,99$ \\
Žiri & $\begin{array}{l}\text { Poljanska } \\
\text { Sora }\end{array}$ & $-0,323$ & pod 90,0 & $-0,018$ & 16,48 & 15,56 & $-0,92$ & $-5,58$ \\
Hotedršica & Hotenjka & $-2,199$ & 95,0 & $-0,034$ & 1,58 & $-0,12$ & $-1,70$ & $-107,59$ \\
Reka & Idrijca & $-3,470$ & 99,9 & $-1,693$ & 107,90 & 23,23 & $-84,67$ & $-78,47$ \\
$\begin{array}{l}\text { Cerkno } \\
\text { Dolenja }\end{array}$ & Cerknica & $-3,636$ & 99,9 & $-0,081$ & 7,66 & 3,62 & $-4,04$ & $-52,74$ \\
$\begin{array}{l}\text { Trebuša } \\
\text { Ajdovščina }\end{array}$ & Hubelj & $-3,948$ & 99,9 & $-0,188$ & 16,43 & 7,05 & $-9,38$ & $-57,09$ \\
\hline
\end{tabular}




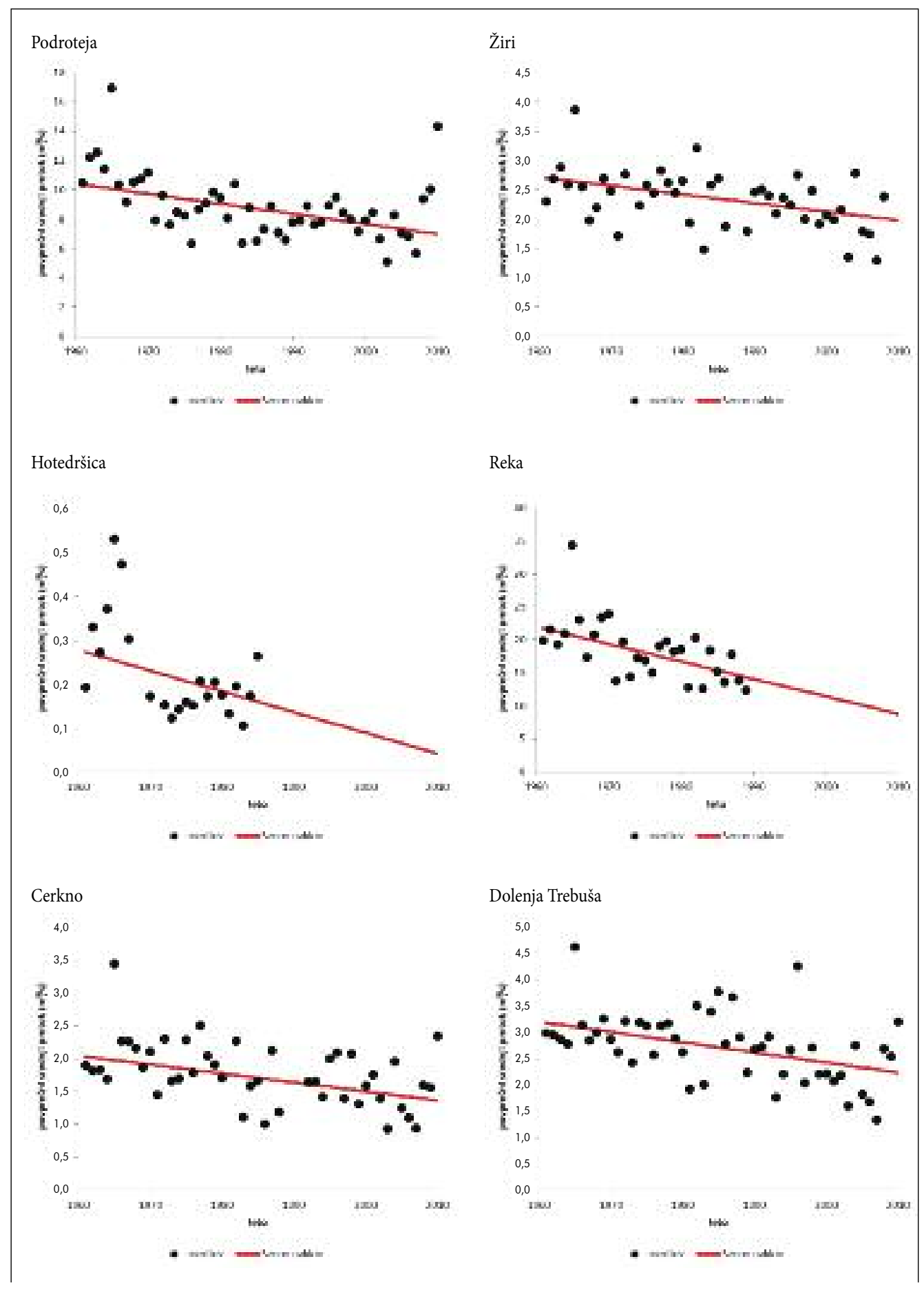




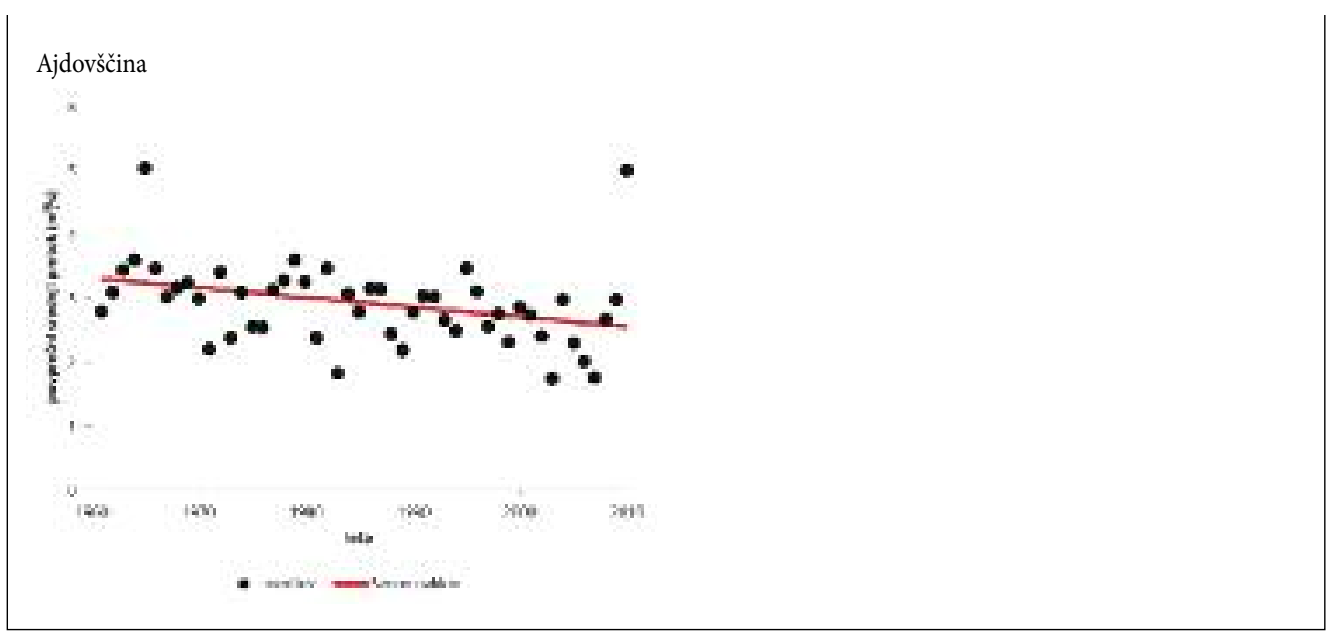

Slika 8: Trendi povprečnih srednjih letnih pretokov $\left(\mathrm{v} \mathrm{m}^{3} / \mathrm{s}\right)$ v obdobju od 1961 do 2010. 


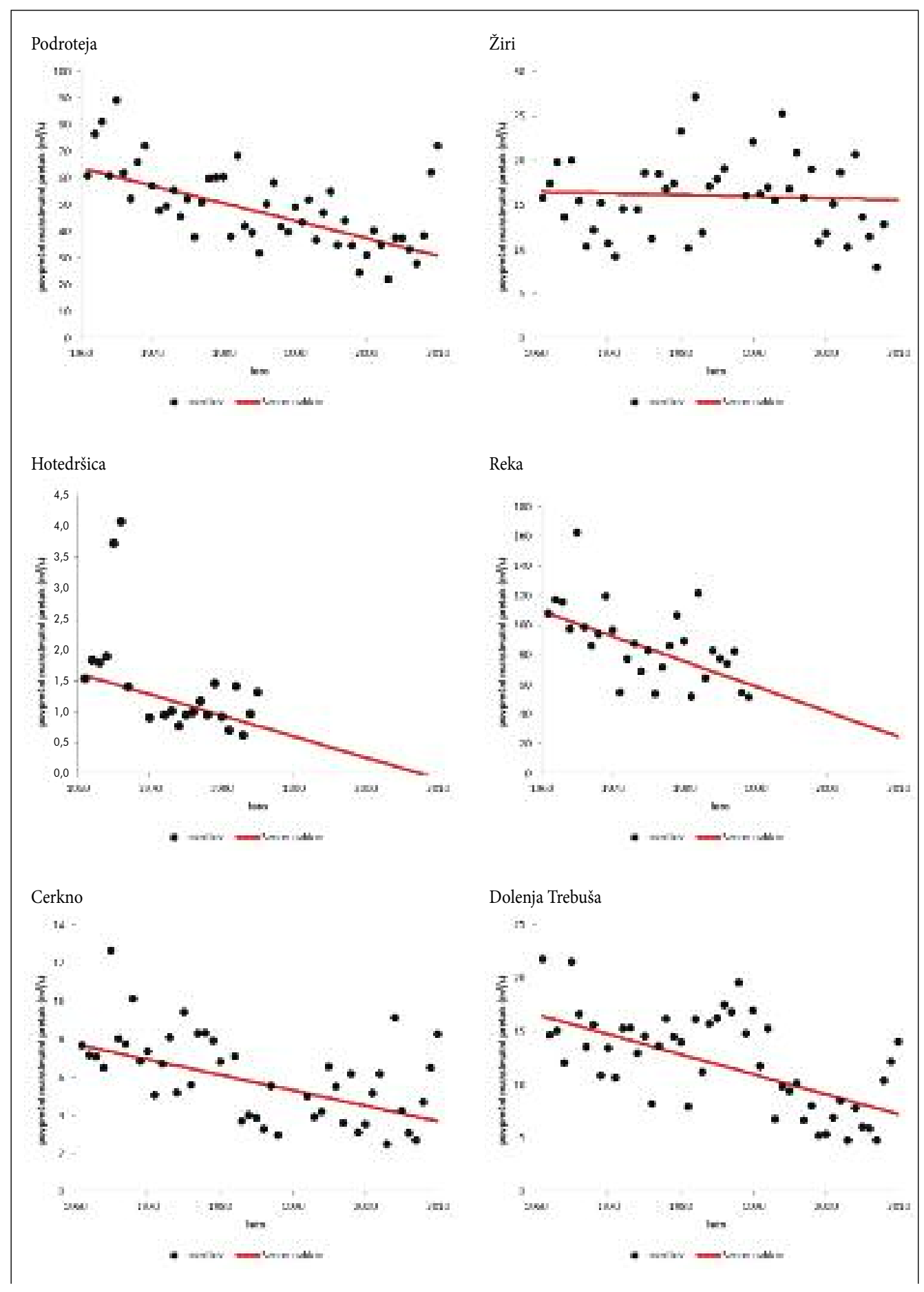




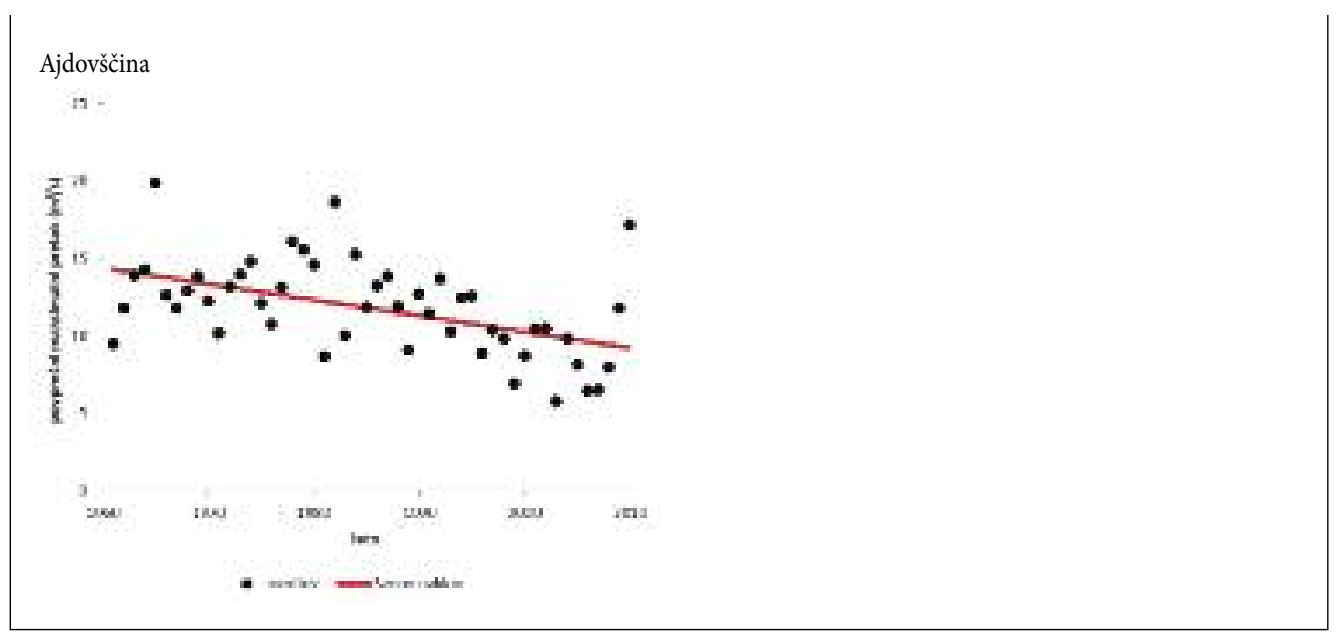

Slika 9: Trendi povprečnih maksimalnih letnih pretokov $\left(\mathrm{v} \mathrm{m}^{3} / \mathrm{s}\right)$ v obdobju od 1961 do 2010. 


\subsubsection{Absolutni maksimalni letni pretoki}

Trendi absolutnih maksimalnih letnih pretokov v obdobju od 1961 do 2010 so na šestih vodotokih oziroma vodomernih postajah padajoči, na Poljanski Sori pri v. p. Žiri pa je trend naraščajoč (preglednica 12, slika 10). Raven zaupanja je nizka, saj na petih obravnavanih vodotokih oziroma vodomernih postajah ne dosega niti $90 \%$. Izjemi sta Idrijca pri v. p. Reka in Trebuščica pri v. p. Dolenja Trebuša z $99 \%$ ravnijo zaupanja.

Absolutni maksimalni letni pretoki so se v obravnavanem obdobju (1961-2010) najbolj zmanjšali na Idrijci pri v. p. Reka in sicer za $326,66 \mathrm{~m}^{3} / \mathrm{s}$ oziroma $74,4 \%$. Podoben delež trendnega upada beleži tudi Hotenjka pri v. p. Hotedršica $\left(-5,71 \mathrm{~m}^{3} / \mathrm{s}\right.$ oziroma $\left.-71,7 \%\right)$. Nekoliko manjše trendne razlike so na Trebuščici pri v. p. Dolenja Trebuša $\left(-18,23 \mathrm{~m}^{3} / \mathrm{s}\right.$ oziroma $\left.-38,5 \%\right)$, na Cerknici pri v. p. Cerkno $\left(-4,45 \mathrm{~m}^{3} / \mathrm{s}\right.$ oziroma $\left.-18,5 \%\right)$, na Idrijci pri v. p. Podroteja $\left(-35,88 \mathrm{~m}^{3} / \mathrm{s}\right.$ oziroma $\left.-17,2 \%\right)$ in na Hublju pri v. p. Ajdovščina $\left(-2,86 \mathrm{~m}^{3} / \mathrm{s}\right.$ oziroma $\left.-8,3 \%\right)$.

Poljanska Sora na v. p. Žiri je edina upoštevana reka, ki beleži naraščajoč trend absolutnih maksimalnih letnih pretokov. $\mathrm{V}$ obravnavanem polstoletnem obdobju so se njeni maksimalni pretoki trendno povečali za $14,24 \mathrm{~m}^{3} / \mathrm{s}$ oziroma $21,3 \%$.

Preglednica 12: Trendi absolutnih maksimalnih letnih pretokov v obdobju od 1961 do 2010.

\begin{tabular}{|c|c|c|c|c|c|c|c|c|}
\hline $\begin{array}{l}\text { vodomerna } \\
\text { postaja }\end{array}$ & vodotok & $\begin{array}{l}\text { Mann- } \\
\text { Kendallov } \\
\text { test }\end{array}$ & $\begin{array}{c}\text { raven } \\
\text { zaupanja }\end{array}$ & $\begin{array}{l}\text { Senov } \\
\text { naklon }\end{array}$ & $\begin{array}{c}\text { trendno } \\
\text { stanje } \\
1961\end{array}$ & $\begin{array}{c}\text { trendno } \\
\text { stanje } \\
2010\end{array}$ & $\begin{array}{l}\text { trendna } \\
\text { razlika } \\
1961-2010\end{array}$ & $\begin{array}{c}\text { trendna } \\
\text { razlika } \\
1961-2010\end{array}$ \\
\hline & & Z & $\%$ & Q & $\mathrm{m}^{3} / \mathrm{s}$ & $\mathrm{m}^{3} / \mathrm{s}$ & $\mathrm{m}^{3} / \mathrm{s}$ & $\%$ \\
\hline Podroteja & Idrijca & $-1,06$ & pod 90,0 & $-0,718$ & 208,61 & 172,73 & $-35,88$ & $-17,20$ \\
\hline Žiri & $\begin{array}{l}\text { Poljanska } \\
\text { Sora }\end{array}$ & 1,34 & pod 90,0 & 0,285 & 66,82 & 81,06 & 14,24 & 21,31 \\
\hline Hotedršica & Hotenjka & $-0,93$ & pod 90,0 & $-0,114$ & 7,96 & 2,25 & $-5,71$ & $-71,73$ \\
\hline Reka & Idrijca & $-2,78$ & 99,0 & $-6,533$ & 438,80 & 112,14 & $-326,66$ & $-74,44$ \\
\hline Cerkno & Cerknica & $-1,12$ & pod 90,0 & $-0,089$ & 24,07 & 19,62 & $-4,45$ & $-18,49$ \\
\hline $\begin{array}{l}\text { Dolenja } \\
\text { Trebuša }\end{array}$ & Trebuščica & $-2,74$ & 99,0 & $-0,365$ & 47,32 & 29,09 & $-18,23$ & $-38,52$ \\
\hline Ajdovščina & Hubelj & $-0,79$ & pod 90,0 & $-0,057$ & 34,49 & 31,63 & $-2,86$ & $-8,29$ \\
\hline
\end{tabular}




\section{Sklep}

Poglavitna spoznanja o spremembah izbranih podnebnih in hidroloških spremenljivk v obdobju med letoma 1961 in 2010 lahko strnemo takole:

- Povprečna letna temperatura zraka je na večini postaj letno narasla od 0,032 do $0,035^{\circ} \mathrm{C}$, kar pomeni, da so se v zadnjega pol stoletja na omenjenih postajah temperature zvišale za $1,59-1,70^{\circ} \mathrm{C}$. Nekoliko manjši temperaturni dvig beležita postaji Slap in Vojsko. Na Slapu se je temperatura zvišala za $0,81^{\circ} \mathrm{C}$, na Vojskem pa za $0,91^{\circ} \mathrm{C}$.

- Letna količina padavin je na večini postaj v povprečju letno upadla od $5 \mathrm{do} 11 \mathrm{~mm}$, kar pomeni, da se je v zadnjega pol stoletja na omenjenih postajah količina padavin znižala za $235-565 \mathrm{~mm}$ oziroma za $10-20 \%$.

- Zmanjšana količina letnih padavin ni posledica zmanjšanja števila dni s padavinami. Število padavinskih dni se je na šestih obravnavanih padavinskih postajah celo povečalo, upadanje pa beležijo le tri padavinske postaje. Tako pozitivne kot negativne razlike $\mathrm{v}$ številu padavinskih dni so večinoma majhne in na šestih od devetih obravnavanih postajah ne dosegajo niti $10 \%$.

- Število dni s snežno odejo je na sedmih od devetih upoštevanih padavinskih postajah upadlo za 21 do 43 dni oziroma za 22 do $46 \%$.

- Trendi absolutnih minimalnih letnih pretokov so na vseh petih vodomernih postajah s popolnim nizom podatkov padajoči. Odstopata le rezultata, ki sta bila pridobljena na temelju krajšega, nepopolnega niza podatkov. Absolutni minimalni pretoki so se zmanjšali za $0,09 \mathrm{do} 0,36 \mathrm{~m}^{3} / \mathrm{s}, \mathrm{v}$ relativnem smislu pa beleži večina vodotokov upad od 17 do $50 \%$.

- Trendi povprečnih minimalnih letnih pretokov so na šestih od sedmih vodomernih postajah padajoči. Povprečni minimalni letni pretoki so se zmanjšali za 0,21 do $1,60 \mathrm{~m}^{3} / \mathrm{s}$, v relativnem smislu pa beleži večina vodotokov upad od 17 do $36 \%$.

- Trendi povprečnih srednjih letnih pretokov v obdobju od 1961 do 2010 so na vseh sedmih vodomernih postajah padajoči. Na vodotokih s popolnim nizom podatkov so se zmanjšali za 0,68 do $3,43 \mathrm{~m}^{3} / \mathrm{s}$, v relativnem smislu pa beleži večina vodotokov upad od 23 do $34 \%$.

- Tudi trendi povprečnih maksimalnih letnih pretokov so na vseh sedmih vodomernih postajah padajoči. Pretoki so se najbolj zmanjšali na reki Idrijci, ki po vodnatosti precej prekaša ostale upoštevane vodotoke. Na v. p. Podroteja je trendna razlika Idrijce $-32,80 \mathrm{~m}^{3} / \mathrm{s}$ oziroma $-52 \%$, na vodomerni postaji Reka pa $-84,67 \mathrm{~m}^{3} / \mathrm{s}$ oziroma $-79 \%$. Velike trendne razlike povprečnih maksimalnih pretokov so opazne tudi na Trebuščici ( $-57 \%)$, na Hublju ( $-36 \%)$ in na Cerknici $(-53 \%)$.

- Trendi absolutnih maksimalnih letnih pretokov so na šestih vodomernih postajah padajoči, na Poljanski Sori pa je trend naraščajoč. Pretoki so se najbolj zmanjšali na Idrijci pri v. p. Reka in sicer za kar $74 \%$, podoben delež trendnega upada pa beleži tudi Hotenjka (-72\%). Nekoliko manjše trendne razlike so na Trebuščici (-39\%), Cerknici (-19\%), Idrijci pri v. p. Podroteja (-17\%) in Hublju (-8\%). V nasprotju z ostalimi vodotoki so se maksimalni pretoki na Poljanski Sori trendno povečali za $21 \%$.

Zahvala: Raziskava je bila izvedena v okviru izdelave študije "Konvencija županov za podnebne spremembe in energijo", ki jo je financirala Občina Idrija, ter temeljnega projekta "Prožnost alpskih pokrajin $z$ vidika naravnih nesreč" (J6-6853) in raziskovalnega programa "Geografija Slovenije "(P6-0101), ki ju financira Javna agencija za raziskovalno dejavnost Republike Slovenije. 


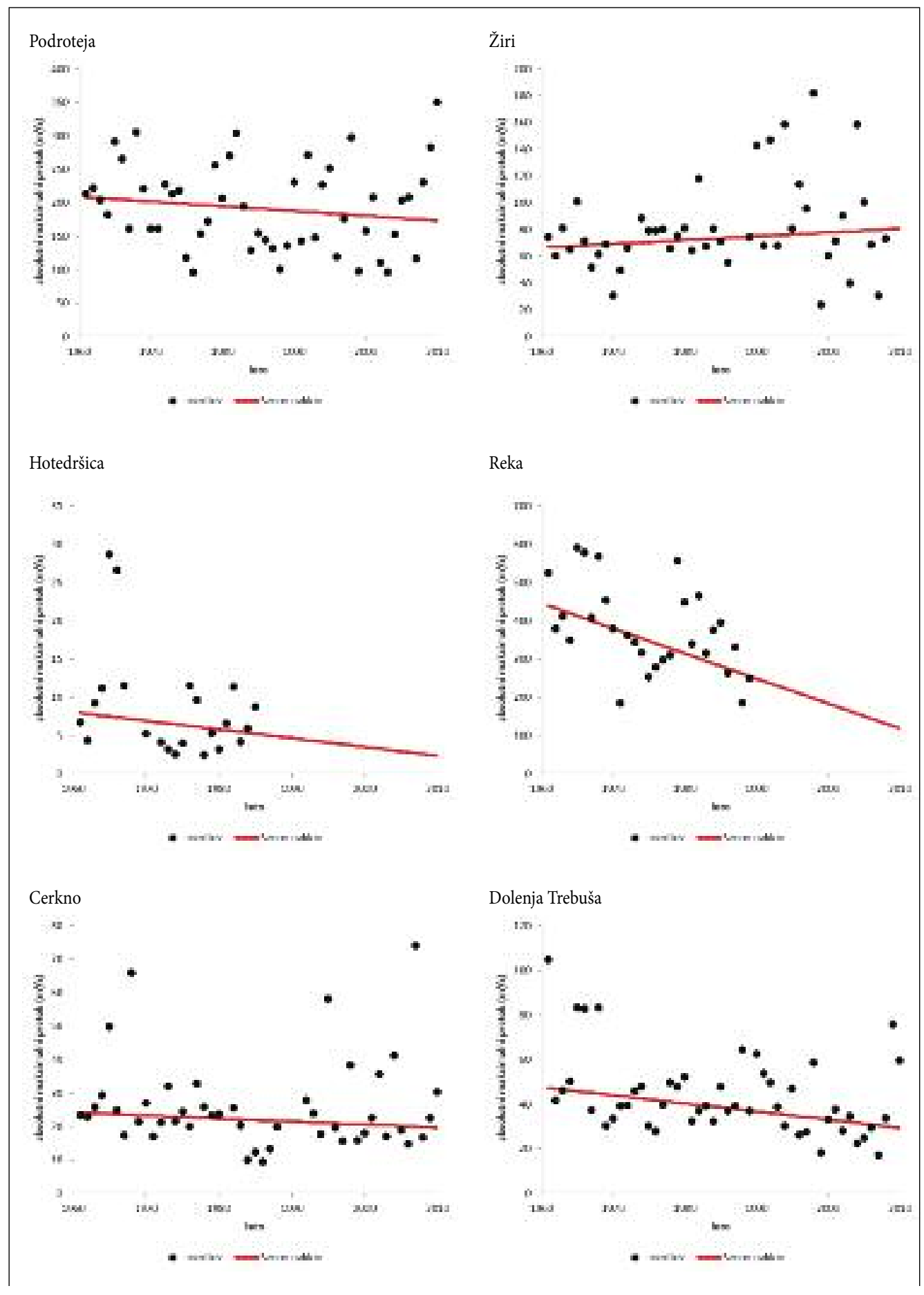




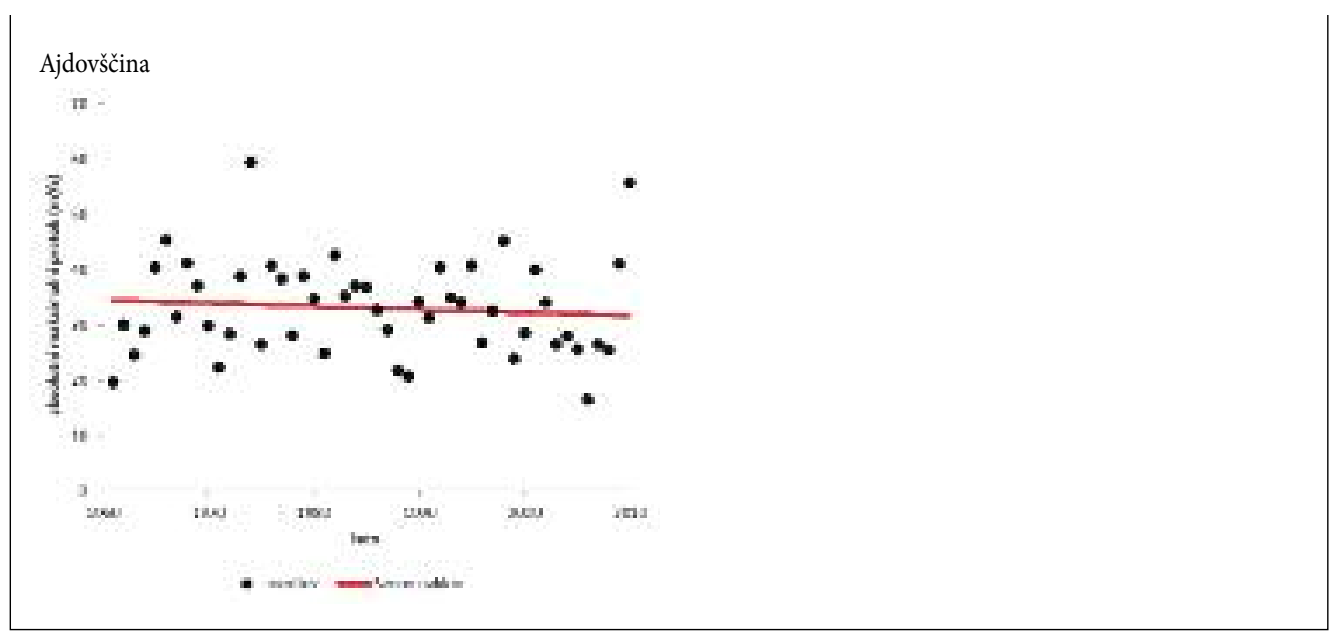

Slika 10: Trendi absolutnih maksimalnih letnih pretokov $\left(\mathrm{v} \mathrm{m}^{3} / \mathrm{s}\right)$ v obdobju od 1961 do 2010. 


\section{Viri in literatura}

Černe, A., Urbanc, M. 1998: Idrijsko hribovje. Slovenija - pokrajine in ljudje. Ljubljana.

Dolinar, M. (ur.) 2010: Spremenljivost podnebja v Sloveniji. Ljubljana.

Frantar, P., Hrvatin, M. 2005: Pretočni režimi v Sloveniji med letoma 1971 in 2000. Geografski vestnik 77-2.

Frantar, P., Kobold, M., Ulaga, F. 2008: Trendi pretokov. Vodna bilanca Slovenije 1971-2000. Ljubljana.

Gabrovec, M., Hrvatin, M., Komac, B., Ortar, J., Pavšek, M., Topole, M., Triglav Čekada, M., Zorn, M. 2014: Triglavski ledenik. Geografija Slovenije 30. Ljubljana.

Gabrovec, M., Ortar, J., Pavšek, M., Zorn, M., Triglav Čekada, M. 2013: The Triglav Glacier between the years 1999 and 2012. Acta geographica Slovenica 53-2. DOI: https://doi.org/10.3986/AGS53202

Hrvatin, M., Zorn, M. 2017: Trendi pretokov rek v slovenskih Alpah med letoma 1961 in 2010. Geografski vestnik 89-2. DOI: https://doi.org/10.3986/GV89201

Kajfež-Bogataj, L. 2006: Podnebne spremembe in nacionalna varnost. Ujma 20.

Kovačič, G. 2016: Trendi pretokov rek jadranskega povodja v Sloveniji brez Posočja. Geografski vestnik 88-2. DOI: https://doi.org/10.3986/GV88201

Kovačič, G., Kolega, N., Brečko Grubar, V. 2016: Vpliv podnebnih sprememb na količine vode in poplave morja v slovenski Istri. Geografski vestnik 88-1. DOI: https://doi.org/10.3986/GV88101

Kraner Šumenjak, T., Šuštar, V. 2011: Parametrični in neparametrični pristopi za odkrivanje trenda $\mathrm{v}$ časovnih vrstah. Acta agriculturae Slovenica 97-3.

Medmrežje 1: http://en.ilmatieteenlaitos.fi/makesens (24.7.2017).

Meze, D. 1987: Hribovske kmetije na Idrijskem in Cerkljanskem. Geografski zbornik 27.

Milošević, D. D., Savić, S. M., Stankov, U., Žiberna, I., Pantelić, M. M., Dolinaj, D., Leščešen, I. 2017: Maximum temperatures over Slovenia and their relationship with atmospheric circulation patterns. Geografie 122-1.

Ogrin, D. 2003: Spreminjanje temperature zraka in padavin po letnih časih v Ljubljani in Trstu v obdobju 1851-2002. Dela 20.

Salmi, T., Määttä, A., Anttila, P., Ruoho-Airola, T., Amnell, T. 2002: Detecting trends of annual values of atmospheric pollutants by the Mann-Kendall test and Sen's slope estimates -the Excel template application MAKESENS. Publications on Air Quality No. 31. Helsinki.

Topole, M., Zorn, M. 2010: Naravnogeografske značilnosti Občine Idrija. Na prelomnici: razvojna vprašanja Občine Idrija, CAPAcities 1. Ljubljana.

Trenberth, K. E., Jones, P. D., Ambenje, P., Bojariu, R., Easterling, D., Klein Tank, A. Parker, D. Rahimzadeh, F., Renwick, J. A., Rusticucci, M., Soden, B., Zhai, P. 2007: Observations: Surface and atmospheric climate change. Climate Change 2007: The Physical Science Basis. Contribution of Working Group I to the Fourth Assessment Report of the Intergovernmental Panel on Climate Change. Cambridge. Medmrežje: https://www.ipcc.ch/publications_and_data/ar4/wg1/en/ch3s3-es.html (24.7.2017).

Ulaga, F., Kobold, M., Frantar, P. 2008: Analiza časovnih sprememb vodnih količin slovenskih rek. Mišičev vodarski dan 19. Maribor.

Zupančič, B. 1998: Padavine. Geografski atlas Slovenije. Ljubljana.

Žiberna, I. 2011: Podnebne spremembe v Sloveniji. Podravina 10-20. 


\section{Summary: Temperature and precipitation trends and river discharge trends in the Idrija Hills}

(translated by DEKS d.o.o.)

Since the mid-nineteenth century, when the Little Ice Age came to an end, temperatures have been rising in Europe and across the globe. In the twentieth century, global mean surface temperatures rose by $0.74 \pm 0.18^{\circ} \mathrm{C}$. The rate of warming over the last 50 years is almost double that over the last 100 years $\left(0.13 \pm 0.03^{\circ} \mathrm{C}\right.$ vs. $0.07 \pm 0.02^{\circ} \mathrm{C}$ per decade $)$. In Europe in the twentieth century, the maximum and minimum winter temperatures rose by $1^{\circ} \mathrm{C}$ per 100 years, and summer temperatures by $0.8^{\circ} \mathrm{C}$ per 100 years. In Slovenia, the average air temperature in the second half of the twentieth century (1956-2005) showed a statistically significant increase of $1.4 \pm 0.6^{\circ} \mathrm{C}$, mostly in towns and less in the countryside. Projections for the twenty-first century forecast a rise in air temperatures during the cold part of the year by $3^{\circ} \mathrm{C}$ (ranging from 1.5 to $7^{\circ} \mathrm{C}$ ), and in the warm part of the year by $3.5^{\circ} \mathrm{C}$ (ranging from 1.5 to $8^{\circ} \mathrm{C}$ ).

Changes in the volume of precipitation in the majority of Slovenian territory are not statistically significant. Nonetheless, there are trends that indicate smaller volumes of precipitation; for example, -36 to $-43 \mathrm{~mm}$ per 100 years for Ljubljana, $-40 \mathrm{~mm}$ per 100 years for Maribor, and $-80 \mathrm{~mm}$ per 100 years for Trieste. In Slovenia there are also fewer days with snow cover. In Ljubljana during the period from 1950 to 2009 the number of days with snow cover decreased by three days per decade (and at the level of the whole country by two to four days per decade). As a consequence of higher winter temperatures and thus a lower share of snow in winter precipitation, there has also been a reduction in snow cover and a reduction in Slovenian glaciers. At Mount Kredarica in the last thirty years the depth of the snow has been below average in comparison to the preceding 130 -year period.

Changes in precipitation volume in connection with land use have an influence on river discharge changes. The majority of hydrometric stations in Slovenia in the last fifty years have shown a falling trend in mean daily discharge, or a decrease in water volume.

This article presents the temperature and precipitation trends at multiple temperature and precipitation stations, and river discharge trends at multiple hydrometric stations in the Idrija Hills between 1961 and 2010.

At the majority of stations studied, the average annual air temperature rose from 0.032 to $0.035^{\circ} \mathrm{C}$ per year, which means that in the last half century the temperature in the area studied rose by 1.59 to $1.70^{\circ} \mathrm{C}$.

The annual precipitation volume at most stations fell on average by 5 to $11 \mathrm{~mm}$ per year, which means that in the last half century precipitation in the area studied has decreased by 235 to $565 \mathrm{~mm}$, or by 10 to $20 \%$. The reduced volume of annual precipitation is not a consequence of fewer days with precipitation. The number of precipitation days actually increased at six precipitation stations, and a decrease was noted at only three precipitation stations. Both the positive and negative differences in the number of precipitation days were mostly small, and at six of the nine precipitation stations they were even below $10 \%$. The number of days with snow cover at seven of the nine precipitation stations studied decreased by 21 to 43 days, or by 22 to $46 \%$.

The trends in absolute minimum annual discharge are falling at all five hydrometric stations with a complete data series. The only exceptions are results obtained based on shorter incomplete data series. The absolute minimum discharges decreased by 0.09 to $0.36 \mathrm{~m}^{3} / \mathrm{s}$, but in the relative sense the majority of watercourses experienced a decrease of 17 to $50 \%$. The trends in average minimum annual discharge are falling at six out of the seven hydrometric stations. The average minimum annual discharge decreased by 0.21 to $1.60 \mathrm{~m}^{3} / \mathrm{s}$, but in the relative sense the majority of watercourses experienced a decrease of 17 to $36 \%$. The trends in average mean annual discharge from 1961 to 2010 were falling at all seven hydrometric stations. For watercourses with a complete data series, there was a decrease of 0.68 to $3.43 \mathrm{~m}^{3} / \mathrm{s}$, but in the relative sense the majority of watercourses experienced a decrease of 23 to $34 \%$. The trends for average maximum annual discharge at all seven hydrometric stations were also 
falling. The discharges fell most on the Idrijca River, which has a considerably higher water volume than the other watercourses studied. At the Podroteja hydrometric station the trend difference for the Idrijca River was $-32.80 \mathrm{~m}^{3} / \mathrm{s}$ or $-52 \%$, and at the Reka hydrometric station $-84.67 \mathrm{~m}^{3} / \mathrm{s}$ or $-79 \%$. Large trend differences in average maximum discharges were also observed on the Trebuščica (-57\%), Hubelj $(-36 \%)$, and Cerknica (-53\%) rivers. The trends for absolute maximum annual discharge were falling at six hydrometric stations, but on the Poljanska Sora River the trend was rising. Discharges decreased the most for the Idrijca River at the Reka hydrometric station (by 74\%), and a similar share of trend decrease was recorded on Hotenjka Creek (-72\%). Somewhat smaller trend differences were recorded for the Trebuščica $(-39 \%)$ and Cerknica $(-19 \%)$ rivers, for the Idrijca River at the Podroteja station $(-17 \%)$, and for the Hubelj River $(-8 \%)$. In contrast to other watercourses, the maximum discharges on the Poljanska Sora River increased by $21 \%$. 